\title{
Alt Konut Piyasaları Bağlamında Hanehalkı ve Konut Özelliklerinin İlişkisi: Ankara Örneği ${ }^{1}$
}

*

\author{
Aysu Uğurlar \\ Tanyel Özelçi Eceral \\ Aslı Gürel Üçer \\ Van Yüzüncü Yıl Üniversitesi \\ Gazi Üniversitesi \\ Gazi Üniversitesi
}

\section{Öz}

Konut piyasası, benzer sosyo-ekonomik yapı içindeki bireyler ve hanehalklarını içeren kendine özgü arz, talep ve mekânsal dinamikler gösteren alt piyasalar bütünüdür. Ankara tarihi boyunca konut politikalarının ilk uygulamalarına bağlı olarak tüm konut sunum ve konut kullanım biçimlerinin ilk örneklerine sahne olmuş ve farklı alt konut piyasaların barındıran bir metropol haline gelmiştir. Bu makale Ankara'da güncel piyasa sunumu araştırması ve hanehalkı anketleri ile gerçekleştirilen alan araştırması verilerinden elde edilen bulgular çerçevesinde gerçekleştirilmiştir. Makalede ilk olarak, Ankara metropoliten kenti konut piyasası/alt piyasalarına ilişkin Hürriyet emlak internet sitesinde 16.12.2013-03.01.2014 tarihleri arasında yer alan Ankara adresli toplam 126.017 konut ilanı aracılı̆̆ıla satılık ve kiralık konutlara ilişkin bilgilerden elde edilen verilerle "Altındă̆, Çankaya, Etimesgut, Gölbaşı, Keçiören, Mamak, Sincan, Yenimahalle" olmak üzere 8 merkez ilçe kapsamında satılık ve kiralık konut sayıları, türleri, satış ve kira değerleri, nitelikleri (yaş, büyüklük ve oda sayısi), değerlendirilerek güncel/mevcut konut piyasasının genel özellikleri ele alınmaktadır. İkinci olarak, bu 8 merkez ilçe içinde 10-26 Şubat 2013 tarihlerinde gerçekleşen \%o3,6 örneklem oranı ile 534 hanehalkı anketlerinden elde edilen veriler ile hanehalkı özellikleri ve konut kullanım özellikleri ilişkisi, sosyo-demografik, sosyo-ekonomik ve mekansal özellikler bağlamında ele alınmaktadır. Farklı alt konut piyasaların, konut (arz yönü) ve kullanıcı/hanehalkları (talep yönü) özellikleri ve ilişkileri açısından ele alan bu makalede, Ankara metropoliten kenti alt konut piyasalarmm, arz-talep ve mekansal dinamikleri ortaya konmaktadır.

Anahtar kelimeler: Konut Piyasası, Alt konut piyasası, hanehalkı özellikleri, konut özellikleri, Ankara.

\footnotetext{
${ }^{1}$ Bu makale "Metropoliten Konut Piyasasında Konut Kullanım Biçimini ve Konut Memnuniyetini Etkileyen Faktörlerin Değerlendirilmesi" başlıklı ve 113K425 Kodlu TUBİTAK Araştırma Projesinden elde edilen verilerden yararlanılarak yazılmıştır.

idealkent (c) Kent Araştırmaları Dergisi (Journal of Urban Studies)

http://idealkentdergisi.com
}

Geliş Tarihi Received Date: 11.12.2017 Kabul Tarihi Accepted Date: 30.12.2018 


\title{
The Relationship Between Household and Housing Characteristics in the Context of Sub-Housing Markets: The Case of Ankara \\ *
}

\author{
Aysu Uğurlar \\ Van Yüzüncü Yıl University
}

\author{
Tanyel Özelçi Eceral \\ Gazi Üniversity
}

\author{
Aslı Gürel Üçer \\ Gazi Üniversity
}

\begin{abstract}
The housing market is a summation of sub-markets with intrinsic supply, demand and spatial dynamics of individuals and households within a similar socioeconomic structure. Throughout its history, Ankara has been the stage to the first examples of all types of housing supply and ownership status (tenure) and has become a metropolis that contains different subhousing markets as a result of the initial implementations of housing policies. This article was authored in accordance with the current market supply research and household surveys conducted in Ankara as well as the findings obtained from the field survey data. In the article, firstly the general characteristics of the current housing market are discussed, based on evaluations on the numbers, types, sales and rent values, qualifications (age, size and number of rooms) of housing for sale and rent in 8 central districts of Ankara, including Altindağ, Çankaya, Etimesgut, Gölbaşı, Keçiören, Mamak, Sincan and Yenimahalle, based on data on the housing market/sub-markets of the metropolitan city of Ankara obtained from 126,017 housing ad posting on the Hürriyet Real Estate website, between 16.12.2013 and 03.01.2014. Secondly, in these 8 central districts, using the data obtained from 534 household surveys with a sampling rate of 3.6\%o, conducted between 10-26 February 2013, the relationship between the characteristics of the household and the characteristics of the housing use is discussed in the context of socio-demographic, socioeconomic and spatial characteristics. In this article, which deals with different sub-housing markets in terms of properties and relations of housing (supply direction) and user/households (demand direction), the supply-demand and spatial dynamics of the sub-housing markets of the metropolitan city of Ankara are revealed.
\end{abstract}

Keywords: Housing Market, Sub-housing market, household characteristics, housing characteristics, Ankara.

idealkent (c) Kent Araştırmaları Dergisi (Journal of Urban Studies) 


\section{Giriş}

Günümüzde Türkiye gibi gelişmekte olan ülkelerde gayrimenkul ve konut öne çıkan sektörler arasındadır. Kentleşme, göç, demografik gelişmeler, hanehalkı yapısının değişimi (yalnız yaşama isteği, evlenme, boşanma vb.) ve konut tüketim alışkanlıklarının farklılaşması gibi etkenler konut gereksinmesinde niteliksel ve niceliksel değişimlere neden olmaktadır. Konutun ekonomik niteliğine bağlı olarak son yıllarda konut arzı, talebi ve fiyatları özellikle büyük kentlerde önemli ölçüde artmıştır. Geçmişten günümüze giderek öne çıkan değişim ve prestij değeri, konutu toplumsal hiyerarşideki statü belirleyen temel göstergelerden biri haline getirmiştir.

Günümüzde gayrimenkul konusunda en yoğun faaliyetin yaşandığ 1 ve tüm kentler arasında konut satış istatistiklerinde lider olan İstanbul, Ankara, İzmir (Dalkılıç ve Aşkın, 2018, s.70) gibi metropoliten kentlerde, konutun prestij ve değişim değeri öne çıkarılarak rant potansiyeli yüksek bölgelerde kentsel projeler yoluyla farklı yaşam tarzlarını yansitan marka konut projeleri (kapalı siteler, rezidanslar vb.) ile kent mekanı dönüştürülmekte, özel sektör eliyle yeniden üretilmektedir. Özel sektörün yanı sıra yerel yönetimler ya da Toplu Konut İdaresi Başkanlığı (TOKİ) tarafından kentsel yenileme/dönüşüm süreçleri ile gerçekleştirilen projeler yoluyla da gecekondu vb. sağliksız konut alanları ve afet riski altındaki alanlar arazi piyasasına daha yüksek rantlarla kazandırılmaya çalışılmakta ve konut fiyatları yükselmektedir. Türel ve Koç (2015), konut satışlarında ve buna bağlı olarak konut sahipliğinde ortaya çıkan artışın, TOKİ tarafından üretilen konutların ve son yıllarda konut kredisi sektörünün büyümesinin etkileri ile ilişkili olduğunu ifade etmektedir. Bununla birlikte, yeni inşaat sektörü (özellikle özel sektör tarafından) düşük gelirli gruplara değil, orta veya yüksek gelirli hanehalklarina hizmet etmektedir (Sarı ve Khurami, 2018).

Konut piyasası, tüketicilerin (hanehalkının) talepleri doğrultusunda üreticilerin, ihtiyacı karşılamaya yönelik konut üretmeleri sürecidir (Öney, 2002). Her bireyin yaşamak isteyeceği bir konut talebi vardır. Konut talebi bireylerin gelirinden, fiyatlardan, beklentilerden, tercihlerden, tamamlayıcı ve ikame malların fiyatlarından etkilenmektedir (Öztürk ve Fitöz: 25; 2009). Temel olarak konut talebi tüketim ve yatırım amaçlı olmak üzere iki kısımdan oluşur. Tüketim amaçlı konut talebi; konut fiyatı, hane halkının geliri, konut kiraları, konut dışındaki mal ve hizmetlerin fiyatları, konutun özellikleri, konut kredisi faiz oranları tarafından belirlenirken; yatırım amaçlı konut talebi sahip olunan konutun getiri oranı, diğer yatırım araçlarının getiri 
oranları, hane halkının serveti ve diğer faktörler tarafından belirlenir. Konut arzı; konut fiyatları, piyasa faiz oranı, konut finansman olanakları, hükümet politikası, arsa üretimi, kentleşme oranı, yapı malzemesi ve yapım teknolojisindeki gelişmeler, yapı malzemelerinin maliyeti ve diğer faktörler tarafından belirlenmektedir (Öztürk ve Fitöz, 2009, s.29).

Konut piyasası, konutların birbirinden farklı özelliklere sahip olmaları (türdeş olmayan) nedeniyle heterojen ürünlerden oluşan bir piyasadır. Konutun hem yatırım arac hem de mal olarak değerlendirilmesi sebebi ile, konut piyasası diğer piyasalara göre farklılıklar göstermektedir (Afşar, Yılmazel ve Yılmazel, 2017, s.195). Farklı niteliklerdeki konutların hizmet düzeyleri de farklı olmakta ve bu farklılaşma, tüketici tercihleri yönünden ikamesi çok sınırlı mal gruplarını ortaya çlkarmaktadır (Davenport, 2003). Bir konut piyasası, nitelikleri bakımından farklı bir fiyatlandırma yapısı ile farklı gelir grubunda hanehalklarına hizmet eden kendine özgü arz ve talebi ile birçok alt piyasaya bölünebilmektedir (Davenport, 2003; Strasheim, 1974). Gribsy (1963), Bourassa, Cantoni ve Hoesli (2007) bir konut alt piyasasınn, birbirleri ile rekabet edebilecek, ikame oranı yüksek ya da ikame edilebilir konutların genellikle benzer gelir gruplarına ya da tüketici kesimine yönelik olduğunu ifade etmektedir. Diğer bir deyişle bir konut alt piyasası, "birbirinin makul ölçüde yakın ikameleri olan bir konutlar kümesi, diğer alt pazarlardaki konutlar için nispeten zayıf ikameler" olarak tanımlanabilir (Bourassa, Hamelink, Hoesli ve MacGregor, 1999, s.162 alıntılayan Wu ve Sharma, 2012, s.746). Rothenberg da (1991), benzer biçimde her bir alt piyasanın talep ile arz edenlerinin yakın ve birbirine denk olduğunu ifade etmektedir (Davenport, 2003). Özetlenecek olursa; bir konut piyasası, kiralık ya da mülk konut olsun benzer sosyo-ekonomik yapı içindeki hanehalklarını içeren kendine özgü arz, talep ve mekânsal dinamikler gösteren alt piyasalar bütünü olarak tanımlanabilir. Bir alt piyasada, değeri (fiyat) konutun ve çevresinin özelliklerine dayalı olarak belirlenen konut birimlerine yönelik talep (mülk konut ya da kiracı), hanehalklarının sosyo-demografik ve sosyoekonomik özellikleri çerçevesinde değişebilen bireysel tercihlerine göre şekillenmektedir (Uğurlar ve Eceral, 2014, s.138).

Ankara tarihi boyunca konut politikalarının ilk uygulamalarına bağlı olarak tüm konut sunum ve konut kullanım biçimlerinin (mülk konut, kiralık konut, lojman vb.) ilk örneklerine sahne olmuş ve farklı dönemlerde uygulanan imar planlarının da etkisi ile günümüzde mekansal, sosyal ve ekonomik açıdan benzerlik ya da farklılık gösteren konut alt piyasalarını barındıran bir metropol haline gelmiştir. Bu makalede ilk olarak, Ankara 
metropoliten kenti konut piyasası/alt piyasalarına ilişkin Hürriyet emlak internet sitesinde 16.12.2013-03.01.2014 tarihleri arasında yer alan Ankara adresli toplam 126.017 konut ilanı aracılığıyla satılık ve kiralık konutlara ilişkin bilgilerden elde edilen verilerle, "Altındağ, Çankaya, Etimesgut, Gölbaşı, Keçiören, Mamak, Sincan, Yenimahalle" olmak üzere 8 merkez ilçe kapsamında satılık ve kiralık konut sayıları, türleri, satış ve kira değerleri, nitelikleri (yaş, büyüklük ve oda sayısı), değerlendirilerek mevcut konut piyasasının genel özellikleri ele alınmaktadır. İkinci olarak, Ankara metropoliten kenti temsil ettiği kabul edilen Ankara Büyükşehir Belediyesi'ne bağlı bu 8 merkez ilçe içinde hanehalkı çeşitliliğini yansıtması çerçevesinde, ilçelerin sosyo-ekonomik yapıları, konut sunum biçimleri ve türleri (toplu konut, apartman, kooperatif, müstakil vb.), gibi faktörler göz önünde bulundurularak belirlenen ve 10-26 Şubat 2013 tarihlerinde gerçekleşen \%o3,6 örneklem oranı ile 534 adet hanehalkı anketinden elde edilen veriler ile hanehalkı özellikleri ve konut kullanım özellikleri ilişkisi; sosyo-demografik, sosyo-ekonomik ve mekansal özellikler bağlamında ele alınmaktadır. Böylece Ankara metropoliten kentinde farklı alt konut piyasaları sadece konut fiyatları ve konut nitelikleri açısından değil ayn zamanda bu piyasaların kullanıcısı olan hanehalkları özellikleri ve birbirleri ile ilişkisi açısından da ele alınmaktadır. Farklı alt konut piyasalarını, konut (arz yönü) ve kullanıcı/hanehalkları (talep yönü) özellikleri ve ilişkileri açısından ele alan bu makalede, Ankara metropoliten kenti alt konut piyasalarının, arz-talep ve mekansal dinamikleri ortaya konularak değerlendirmektedir.

\section{Piyasa Sunumu (Arz) Çerçevesinde Ankara Metropoliten Kenti Alt Konut Piyasalarının Genel Özellikleri}

Türkiye'de konut piyasasında konut arzının ana aktörleri olarak konut üretimi, en geniş hali ile kamu (yerel yönetimler, TOKİ vb.) ve özel girişimciler (bireysel, büyük ve küçük ölçekli firmalar vb.) tarafından gerçekleştirilmektedir. Türkiye'de mülk (konut sahipliği) ya da kiralık olmak üzere farklı konut kullanım biçimleri değerlendirildiğinde; Cumhuriyetin ilk yıllarından itibaren mülk konut politikası desteklense de, mülk konut politikasının en önemli parçası olan konut satın alacaklara yeterli kredi desteği sağlanması mümkün olamamıştır (Türel, 1996). Türkiye'de özellikle kentsel alanlarda yaygın olan kiralık konut stoku ise kiralık konut sunum politikaları ile değil rant aktarımları hacmi ile belirlenmiştir (Balamir, 1996). Türkiye İstatistik Kurumu'nun (TÜiK) "Gelir ve Yaşam Koşulları Araştırmasına" göre 2013- 
2017 yılları arasında Türkiye'de ev sahipliği \%60,7'den 59,7'e düşerken kiracllı̆̆ı \%21,3'den 24,4'e yükseldiği görülmektedir (TÜİK 2018). Bu rakamlar, iki konut kullanım biçiminin de konut piyasasında önemli ölçüde yeri olduğunu göstermektedir.

Kentsel gelişim açısından Ankara'nın Cumhuriyet tarihinde önemli bir yeri vardır. Ankara, başkent oluşundan itibaren konut politikalarının uygulamalarına bağlı olarak tüm konut sunum ve konut kullanım biçimlerinin uygulama alanı olmuştur. Ankara metropoliten kenti merkez ilçeleri arasında en yüksek kiracıllk oranına sahip olan ilçeler Altındağ (\%40), Etimesgut (\%37) ve Sincan (\%37)'dır. 2011 yılı TÜİK verilerine göre, Ankara'da toplam hanehalkı sayısı 1.435.174 olup, bunun \%60,9'u ev sahibi, \%30,2'si kiracı, \%2,9'u lojmanda oturan ve \%6'sı ev sahibi değil ama kira ödememektedir. 2013 yılı Ankara Ulaşım Ana Planı² verilerine göre Ankara metropoliten kenti merkez ilçeleri arasında en yüksek kiracılık oranına sahip olan ilçeler Altındağ $(\% 37,4)$, Çankaya $(\% 35,2)$ ve Yenimahalle $(\% 32,9)$; en yüksek ev sahipliği oranına sahip olan ilçeler ise Gölbaşı $(\% 69,9)$ ve Sincan (\%68,2)'dır (Tablo 1). 2002-2011 yılları arasında Ankara'da yeni konutların ilçelere göre dağılımında Keçiören'in \%19,8 ile en yüksek orana sahip olduğu görülmektedir. Keçiören'i; Etimesgut (\%16), Çankaya (\%14,9), Mamak $(\% 13,9)$, Yenimahalle $(\% 13,8)$, Sincan $(\% 12,8)$, Altındağ $(\% 6,5)$ ve Gölbaşı (\%2,2) ilçeleri izlemektedir (Ankara Kalkınma Ajansı, 2013, s.222).

Tablo 1. 2013 yılı Ankara merkez ilçelerinin konut kullanım biçimi dağılımı (\%)

\begin{tabular}{l|c|c|c|c|c}
\hline İlçeler & $\begin{array}{c}\text { Ev Sahibi } \\
\text { Hanehalkı } \\
\text { Sayısı }\end{array}$ & $\begin{array}{c}\text { Ev Sahibi } \\
\text { Hanehalk1 } \\
\text { Oranı (\%) }\end{array}$ & $\begin{array}{c}\text { Kirac1 } \\
\text { Hanehalk1 } \\
\text { Sayıs1 }\end{array}$ & $\begin{array}{c}\text { Kiracı Ha- } \\
\text { nehalk1 } \\
\text { Oranı (\%) }\end{array}$ & $\begin{array}{c}\text { Toplam } \\
\text { Hanehalkı } \\
\text { Sayısı }\end{array}$ \\
\hline Altındağ & 1.831 & 58,3 & 1.173 & 37,3 & 3.142 \\
\hline Çankaya & 4.874 & 56,7 & 3.026 & 35,2 & 8.594 \\
\hline Etimesgut & 2.737 & 65,7 & 1.227 & 29,5 & 4.164 \\
\hline Gölbaşı & 562 & 69,9 & 198 & 24,6 & 804 \\
\hline Keçiören & 5.698 & 65,3 & 2.668 & 30,6 & 8.731 \\
\hline Mamak & 3.985 & 65,5 & 1.870 & 30,7 & 6.086 \\
\hline Sincan & 2.535 & 68,2 & 1.050 & 28,2 & 3.718 \\
\hline Yenimahalle & 4.933 & 61,6 & 2.636 & 32,9 & 8.006 \\
\hline 8 ilçe toplam & 27.155 & 62,8 & 13.848 & 32,0 & 43.245 \\
\hline
\end{tabular}

Kaynak: UAP, 2014

Bu bölümde, Ankara'da mevcut konut piyasasına ilişkin genel bir bilgi edinebilme amacı ile "Hürriyet Emlak" internet sitesinde 16.12.2013-03.01.2014

\footnotetext{
${ }^{2} 2013$ yılı Ankara Ulaşım Ana Planı verileri \%3 örneklem ile yapılan hanehalkı anketlerine dayanmaktadır.
} 
tarihleri arasında yer alan Ankara adresli toplam 126.017 konut ilanı aracil1ğıyla satılık ve kiralık konutlara ilişkin veriler ele alınmakta ve ilgili tarihe ilişkin güncel piyasa sunumu (arz) değerlendirilmektedir. Bu kapsamda Ankara metropoliteni içinde 8 merkez ilçe adresli konut ilanları (121.858), Ankara adresli toplam konut ilanlarının \%96,7sini oluşturmaktadır. Her bir ilçe farklı alt konut piyasalarını temsil etmektedir. Konut ilanlarının \%87,5'i satılık; \%12,5'i ise kiralık konut ilanlarından oluşmaktadır. Bu ilanlardan elde edilen veriler; ilçelere göre satılık ve kiralık konut sayıları, türleri, satış ve kira değerleri, nitelikleri (yaş, büyüklük ve oda sayısı), başlıkları altında değerlendirilmiştir. Ulaşılan bulgular ile Ankara metropoliten kenti merkez ilçelerinin mevcut konut piyasasına göre ortaya çıkan genel özellikleri analiz edilmektedir.

Ankara'da satılık konut ilanlarının ilçelere dağılımı değerlendirildiğinde (Tablo 2.); en fazla Çankaya (\%25,3), Keçiören (\%24,8) ve Etimesgut $(\% 16,6)$ ilçelerinde olduğu izlenmektedir. Satılık konut ilanının en az olduğu ilçeler ise Gölbaşı $(\% 1,5)$, Altındağ $(\% 3)$ ve Sincan $(\% 3,7)$ 'dır. Kiralık konut, ilanlarının ilçelere göre dağılımı değerlendirildiğinde ise yarıya yakınının Çankaya'da (\%43,8), buna karşılık en az kiralık konut ilanının Sincan'da (\%0,8) olduğu görülmektedir.

Tablo 2. Ankara emlak ilanlarının sayısı ve ilçelere göre dağılımı (\%)

\begin{tabular}{l|r|r|r|r|r|r}
\hline \multirow{2}{*}{ İlçeler/Alt piyasalar } & \multicolumn{2}{|c|}{ Satılık Konut } & \multicolumn{2}{c|}{ Kiralık Konut } & \multicolumn{2}{c}{ Toplam Iccinde } \\
\cline { 2 - 7 } & Say1 & $\%$ & Say1 & $\%$ & Say1 & $\%$ \\
\hline Altındağ & 3139 & 3,0 & 245 & 1,6 & 3384 & 2,8 \\
\hline Çankaya & 26789 & 25,3 & 6641 & 43,8 & 33430 & 27,6 \\
\hline Etimesgut & 17553 & 16,6 & 3099 & 20,4 & 20652 & 17,1 \\
\hline Gölbaşı & 1619 & 1,5 & 275 & 1,8 & 1894 & 1,6 \\
\hline Keçiören & 26272 & 24,8 & 1189 & 7,8 & 27461 & 22,7 \\
\hline Mamak & 11292 & 10,6 & 658 & 4,3 & 11950 & 9,8 \\
\hline Sincan & 3867 & 3,7 & 114 & 0,8 & 3981 & 3,3 \\
\hline Yenimahalle & 15318 & 14,5 & 2966 & 19,5 & 18284 & 15,1 \\
\hline Toplam & 105849 & 100,0 & 15187 & 100 & 121036 & 100,0 \\
\hline
\end{tabular}

\section{Konut Türleri}

Konut ilanlarında konutlar, apartman dairesi, villa, müstakil ev, rezidans, loft daire, çiftlik evi, köy evi, dağ evi, köşk/konak, kooperatif olarak sınıflandırılmaktadır. Satılık ve kiralık toplam konutların türlerine 
göre dağılımı değerlendirildiğinde (Tablo 3), konutların \%94,6'sını apartman dairesi, \%4'ünü ise villa / müstakil ev türü konutların oluşturduğu; diğer konut türlerinin ise $(\% 1,4)$ çok küçük bir paya sahip olduğu görülmektedir. Konut türü açısından Ankara'da çeşitliliğin sınırlı olduğu söylenebilir. Alt konut piyasaları/ilçeler açısından satılık konutların türleri değerlendirildiğinde, Gölbaşı ve Yenimahalle hariç tüm ilçelerde satılık konutların \%95'den fazlasının apartman dairesi olduğu izlenmektedir. Gölbaşı'nda ise satılık konutlar içinde apartman dairesi $\% 43,6$ oranında iken; villa ve müstakil evlerin toplam oranı $\% 49,8$ 'e ulaşmaktadır. Yenimahalle'de de satılık konutların \%85,3'ünü apartman daireleri, $\% 13,5$ 'ini ise villa ve müstakil evler oluşturmaktadır. Ankara'da villa/müstakil ev türü konutların Gölbaşı (İncek bölgesi) ve Yenimahalle (Batıkent ve Çayyolu ${ }^{3}$ bölgeleri) ilçelerinde yoğunlaşmakta olduğu bilinmektedir. İlçeler açısından kiralık konutların türleri değerlendirildiğinde, Gölbaşı ve Yenimahalle hariç tüm ilçelerde kiralık konutların $\% 90$ 'dan fazlasının apartman dairesi olduğu izlenmektedir.

Tablo 3. İlçelere/Alt Piyasalara göre konut türleri

\begin{tabular}{|c|c|c|c|c|c|c|c|c|c|c|c|c|c|c|c|c|c|c|}
\hline $\begin{array}{l}\text { Konut } \\
\text { Türü// } \\
\text { İlçe }\end{array}$ & 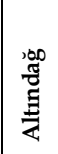 & $0^{\circ}$ & 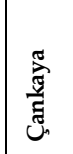 & $\therefore$ & 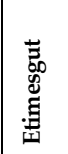 & $0^{\circ}$ & 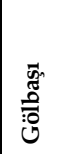 & $\therefore$ & 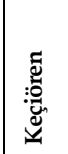 & $0^{\circ}$ & 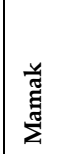 & $0^{\circ}$ & ॠ్ & $0^{0}$ & 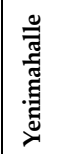 & $0^{\circ}$ & 胥 & $\circ^{\circ}$ \\
\hline $\begin{array}{l}\text { Apartman } \\
\text { Daire }\end{array}$ & 3317 & 98,02 & 31927 & 95,50 & 19632 & 95 & 835 & 44,09 & 27357 & 99,62 & 11891 & 99,51 & 3884 & 97,56 & 15691 & 85,82 & 114534 & 94,6 \\
\hline Rezidans & 2 & \begin{tabular}{|l|}
0,06 \\
\end{tabular} & 618 & 1,85 & 434 & 2,10 & 80 & 4,22 & 14 & 0,05 & 11 & 0,09 & 0 & 0,00 & 80 & \begin{tabular}{|l|}
0,44 \\
\end{tabular} & 1239 & 1,0 \\
\hline Villa & 4 & \begin{tabular}{|l|}
0,12 \\
\end{tabular} & 666 & 1,99 & 512 & 2,48 & 824 & 43,51 & 23 & 0,08 & 24 & 0,20 & 56 & 1,41 & \begin{tabular}{|l}
1648 \\
\end{tabular} & \begin{tabular}{|l|}
9,01 \\
\end{tabular} & 3757 & 3,1 \\
\hline Müstakil & 29 & 0,86 & 68 & 0,20 & 31 & \begin{tabular}{|l|}
0,15 \\
\end{tabular} & 84 & 4,44 & 17 & 0,06 & 14 & 0,12 & 17 & 0,43 & 758 & 4,15 & 1018 & 0,9 \\
\hline $\begin{array}{l}\text { Komple } \\
\text { Bina }\end{array}$ & 21 & 0,62 & 123 & 0,37 & 16 & 0,08 & 12 & 0,63 & 29 & 0,11 & 5 & 0,04 & 1 & 0,03 & 68 & \begin{tabular}{|l|}
0,37 \\
\end{tabular} & 275 & 0,2 \\
\hline Diğer* & 11 & 0,33 & 28 & 0,08 & 27 & 0,13 & 59 & 3,12 & 21 & 0,08 & 5 & 0,04 & 23 & 0,58 & 39 & 0,21 & 213 & 0,2 \\
\hline Toplam & 3384 & 100 & 33430 & 100 & 20652 & 100 & 1894 & 100 & 27461 & 100 & 11950 & 100 & 3981 & 100 & 18284 & \begin{tabular}{|l|}
100 \\
\end{tabular} & 121036 & 100,0 \\
\hline$\%$ & 2,8 & & 27,6 & & 17,1 & & 1,6 & & 22,7 & & 9,9 & & 3,3 & & \begin{tabular}{|l|}
15,1 \\
\end{tabular} & & & \\
\hline
\end{tabular}

*Loft daire, çiftlik evi, köy evi, dağ evi, köşk/konak, yazlık, kooperatif

\section{Satılık ve Kiralık Konut Değerleri}

Konut ilanlarında satılık konutların piyasa satış değerleri (Tablo 4) incelendiğinde, konutun satış değerinin en az olduğu ilçe Sincan, en fazla olduğu ilçe ise Gölbaşı'dır. Kiralık konutların piyasa kira değerleri (Tab-

\footnotetext{
${ }^{3}$ Alan Çalışmasının yapıldığı tarihte Çayyolu bögesi Yenimahalle ilçesi sınırlarında yer almakta idi.
} 
lo 5) incelendiğinde ise kira değerlerinin en az olduğu ilçenin Sincan, en yüksek olduğu ilçelerin ise sırasıyla Çankaya, Gölbaşı ve Yenimahalle olduğu görülmektedir.

Tablo 4. İlçelere göre satılık konutların satış değeri (bin TL)

\begin{tabular}{|c|c|c|c|c|c|c|c|c|c|c|c|}
\hline İlçeler & $\begin{array}{l}100000 \\
\text { ve altı }\end{array}$ & $\%$ & $\begin{array}{l}100001- \\
150000 \\
\end{array}$ & $\%$ & $\begin{array}{l}\text { 150001- } \\
250000\end{array}$ & $\%$ & $\begin{array}{l}250001- \\
400000\end{array}$ & $\%$ & $\begin{array}{l}400001 \\
+ \\
\end{array}$ & $\%$ & Toplam \\
\hline Altındağ & 736 & 22,0 & 1348 & 40,3 & 969 & 29,0 & 235 & 7,0 & 53 & 1,6 & 3341 \\
\hline Çankaya & 719 & 2,7 & 3500 & 13,1 & 9850 & 36,8 & 8294 & 31,0 & 4428 & 16,5 & 26791 \\
\hline Etimesgut & 3185 & 18,1 & 5776 & 32,9 & 5744 & 32,7 & 2458 & 14,0 & 413 & 2,3 & 17576 \\
\hline Gölbaşı & 112 & 6,9 & 188 & 11,6 & 345 & 21,4 & 409 & 25,3 & 560 & 34,7 & 1614 \\
\hline Keçiören & 5105 & 19,4 & 9588 & 36,5 & 8527 & 32,5 & 2497 & 9,5 & 555 & 2,1 & 26272 \\
\hline Mamak & 3414 & 30,2 & 4980 & 44,1 & 2521 & 22,3 & 374 & 3,3 & 15 & 0,1 & 11304 \\
\hline Sincan & 2292 & 59,2 & 1267 & 32,7 & 269 & 7,0 & 26 & 0,7 & 15 & 0,4 & 3869 \\
\hline Yenimahalle & 1189 & 7,8 & 1740 & 11,4 & 4814 & 31,4 & 4496 & 29,4 & 3079 & 20,1 & 15318 \\
\hline Toplam & 16752 & 15,8 & 28387 & 26,8 & 33039 & 31,1 & 18789 & 17,7 & 9118 & 8,6 & 106085 \\
\hline
\end{tabular}

Tablo 5. İlçelere göre kiralık konutların kira değeri (TL)

\begin{tabular}{|c|c|c|c|c|c|c|c|c|c|c|c|}
\hline İlçeler & $\begin{array}{c}500 \text { ve } \\
\text { altı }\end{array}$ & $\%$ & $\begin{array}{l}501- \\
1000\end{array}$ & $\%$ & $\begin{array}{l}1001- \\
1500\end{array}$ & $\%$ & $\begin{array}{l}1501- \\
2000 \\
\end{array}$ & $\%$ & $2001+$ & $\%$ & Toplam \\
\hline Altın & 116 & 48,1 & 117 & 48,5 & 8 & 3,3 & 0 & 0,0 & 0 & 0,0 & 241 \\
\hline Çankaya & 195 & 2,9 & 2482 & 37,5 & 1842 & 27,8 & 737 & 11,1 & 1362 & 20,6 & 6618 \\
\hline Etimesgut & 1344 & 43,7 & 1621 & 52,6 & 88 & 2,9 & 23 & 0,7 & 3 & 0,1 & 3079 \\
\hline Gölbaşı & 19 & 7,9 & 96 & 40,2 & 71 & 29,7 & 17 & 7,1 & 36 & 15,1 & 239 \\
\hline Keçiören & 587 & 49,4 & 555 & 46,7 & 27 & 2,3 & 5 & 0,4 & 15 & 1,3 & 1189 \\
\hline Mamak & 37 & 55,5 & 260 & 38,4 & 14 & 2,1 & 4 & 0,6 & 23 & 3,4 & 677 \\
\hline Sincan & 1( & 91,1 & 10 & 8,9 & 0 & 0,0 & 0 & 0,0 & 0 & 0,0 & 112 \\
\hline Yeni & & 18,2 & 1272 & 42,9 & 736 & 24,8 & 236 & 8,0 & 181 & 6,1 & 2966 \\
\hline Toplam & 3280 & 21,7 & 6413 & 42,4 & 2786 & 18,4 & 1022 & 6,8 & 1620 & 10,7 & 15121 \\
\hline
\end{tabular}

Konut ilanlarında Ankara metropoliten kenti toplamında satılık konutların \%16'sı düşük değerlere (100bin TL'den düşük) sahipken, \%26'sı yüksek değerlere (250bin TL'den yüksek), \%58'i ise orta değerlere (100bin250bin TL arası) sahiptir. Kiralık konutların ise \%22'si düşük (500TL'den düşük), \%18'i yüksek (1500 TL'den yüksek), \%60' 1 ise orta değerlere (500$1500 \mathrm{TL}$ arası) sahiptir. Satılık ve kiralık konutların satış ve kira değerleri bir arada değerlendirildiğinde, Ankara'da satılık ve kiralık konut piyasasında ilçeler bazında önemli farklılıklar olduğu ortaya çıkmaktadır. Sincan'da yüksek satılık ve kiralık konut değerlerine rastlanmamakta; buna karşılık Çankaya'da düşük değerli satılık ve kiralık konut bulunmamaktadır. Yenimahalle, Gölbaşı ve Çankaya'da satılık konutların yarıdan faz- 
lası yüksek değerlere sahiptir. Çankaya'da orta-yüksek, Gölbaşı ve Yenimahalle' de ise yüksek-orta değerler ağırlıklı olmaktadır (Harita 1). Mamak ve Altındağ'da yüksek değerli satılık konut oranları oldukça düşük iken Keçiören ve Etimesgut'ta belli oranlarda yer almaktadır. Kiralık konut değerleri açısından değerlendirildiğinde Mamak, Altındağ, Keçiören ve Etimesgut' ta kiralık konutların neredeyse tamamı düşük ve orta değerlere sahiptir. Yenimahalle, Gölbaşı ve Çankaya'da orta kiralık konut değeri \%65'in üzerindeyken, yüksek kiralık konut değeri Çankaya' da \%32, Gölbaşı'nda \%22 ve Yenimahalle'de \%14'tür (Harita 2.).

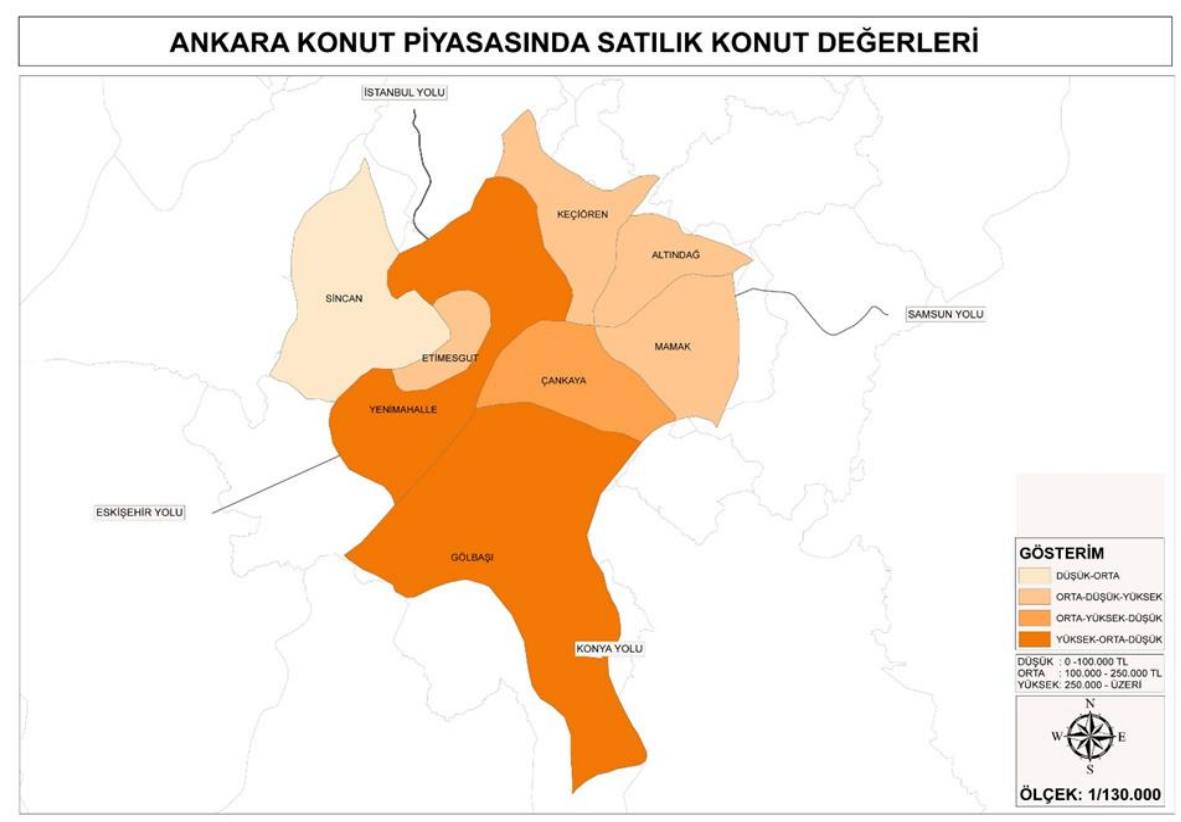

Satılık *Düşük-100binTL'den az *Orta-100bin-250bin TL *Yüksek-250bin TL üzeri Harita 1. Ankara konut piyasasında satılık konut değerleri 


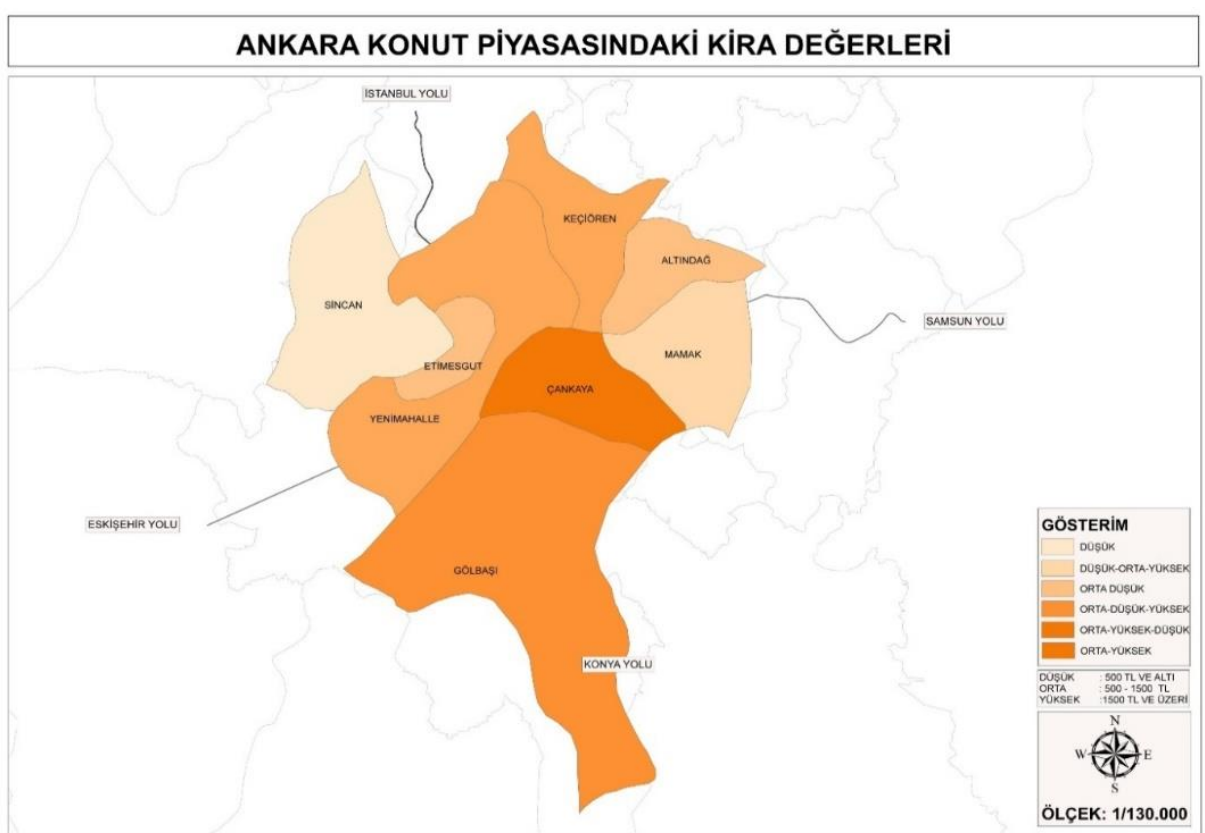

Kiralık *Düşük-500TLden az *Orta-500TL-1500 TL *Yüksek-2000TL üzeri

Harita 2. Ankara konut piyasasında kiralık konut değerleri

\section{Konutların Büyüklükleri ve Oda Sayıları}

Konutların büyüklükleri değerlendirildiğinde konutların yarısından fazlasinın $90-150 \mathrm{~m}^{2}(\% 64,7)$ büyüklüğünde olduğu görülmektedir. $90 \mathrm{~m}^{2} \mathrm{den}$ küçük $(\% 8,5)$ ve $150 \mathrm{~m}^{2}$ den büyük $(\% 26,8)$ konutlar ile birlikte ele alındığında Ankara'da konut büyüklüğü açısından bir çeşitliliğin olduğu söylenebilir. $60 \mathrm{~m}^{2}$ den küu̧ük ve $61-89 \mathrm{~m}^{2}$ büyüklügüündeki konutların en fazla Etimesgut'ta, 90-120 $\mathrm{m}^{2}$ büyüklüğündeki konutların en fazla Keçiören'de, 121$150 \mathrm{~m}^{2}$ büyüklüğündeki konutların en fazla Çankaya'da, 151-180 $\mathrm{m}^{2}$ büyüklüğündeki konutların en fazla Yenimahalle'de, $180 \mathrm{~m}^{2}$ den büyük konutların ise en fazla Çankaya'da olduğu görülmektedir. Küçük $\left(90 \mathrm{~m}^{2}\right.$ den küçük) konutların Etimesgut'ta, ortalama büyüklükteki (90-120 m²) konutların Keçiören'de ve büyük konutların (121 $\mathrm{m}^{2}$ den büyük) Çankaya ve Yenimahalle'de yoğunlaştığı söylenebilir (Harita 3). Konutların oda sayısındaki dağılım büyüklük ile benzer olup konutların yarısından fazlası (\%59,3) 3 odal1dır. 1-2 odalı küçük konutların en fazla Etimesgut'ta (\%27,4), 3 odalı konutların en fazla Keçiören'de (\%26), 4 ve daha fazla odalı konutların ise en fazla Çankaya'da olduğu görülmektedir. 


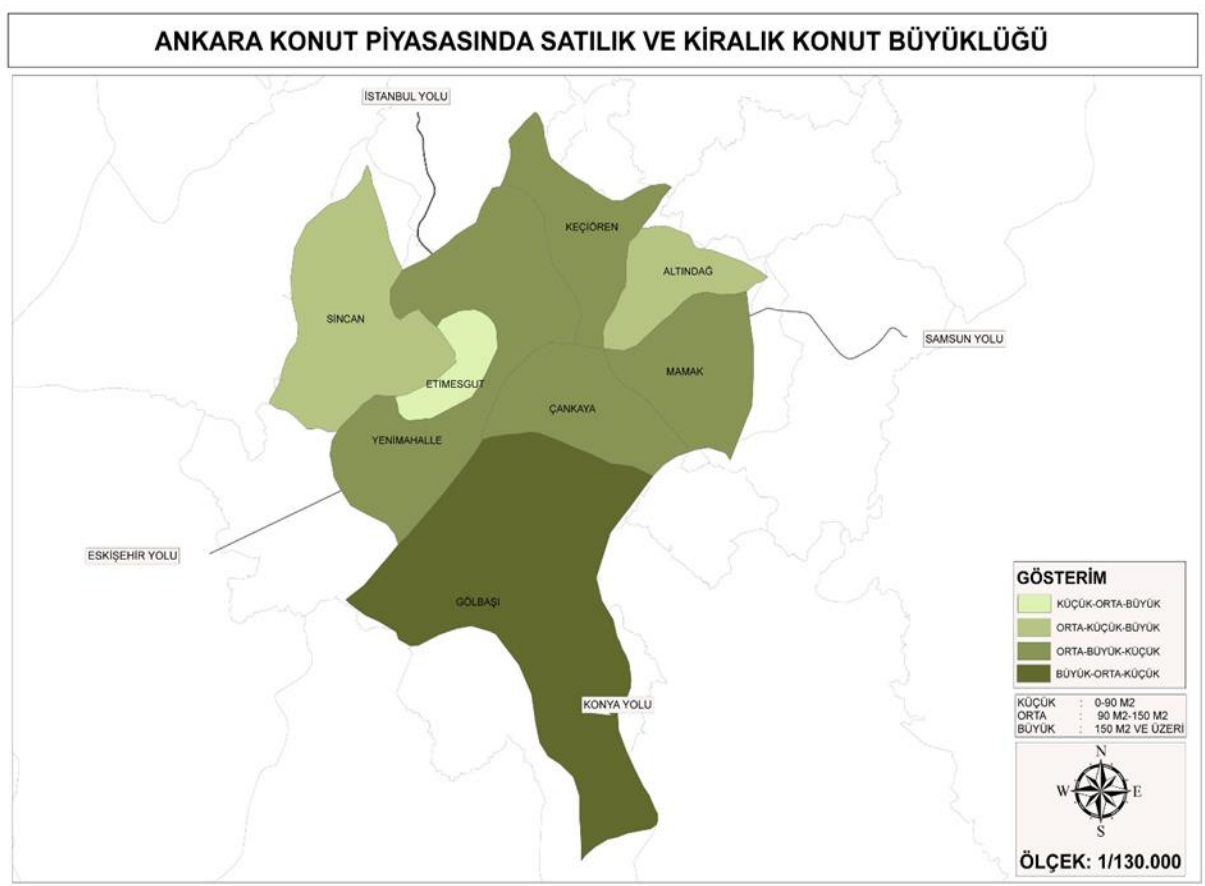

Konut Büyüklük *Küçük-90m2'den küçük *Orta-90m2-150m2 *Büyük 150m2'den büyük

Harita 3. Ankara konut piyasasında satılık ve kiralık konut büyüklüğü

\section{Konutların Yaşı}

Konut piyasasındaki konutların yaşları (Tablo 6) değerlendirildiğinde en fazla 0-1 yaşındaki yeni (bazıları inşaat aşamasında olan) konutların $(\% 41,1)$, en az ise 31 yaşından büyük konutların $(\% 1,9)$ bulunduğu görülmektedir. Konutların yarıdan fazlasının yeni (0-1 yaş) olduğu ilçeler sırasıyla Altındağ, Etimesgut ve Mamak'tır. Sincan 11-20, Çankaya 21-30, Gölbaşı ise 2-10 yaş aralığındaki konutların yoğunlaştığı ilçelerdir. Yeni konutların (0-1 yaş) daha çok satılık, buna karşıllı 10 yaşından büyük konutların daha çok kiralık olarak konut piyasasında yer aldığı sonucuna ulaşılabilir. Ankara'da mevcut konut piyasasındaki satılık ve kiralık konutların yaşları ağırlıkla 2-20 yıllık orta yaşlı konutlar ve 0-1 yıllık yeni konutlardır (Harita 4). 
Tablo 6. İlçelere göre konutların yaşları

\begin{tabular}{l|r|r|r|r|r|r|r|r|r|r|r}
\hline İlçeler & $\mathbf{0 - 1}$ & $\mathbf{\%}$ & $\mathbf{2 - 1 0}$ & $\mathbf{\%}$ & $\mathbf{1 1 - 2 0}$ & $\mathbf{\%}$ & $\mathbf{2 1 - 3 0}$ & $\mathbf{\%}$ & $\mathbf{3 1 +}$ & $\mathbf{\%}$ & Toplam \\
\hline Altındă̆ & 2032 & 64,2 & 586 & 18,5 & 133 & 4,2 & 249 & 7,9 & 164 & 5,2 & 3164 \\
\hline Çankaya & 4565 & 16,7 & 9580 & 35,1 & 8446 & 30,9 & 3263 & 11,9 & 1462 & 5,4 & 27316 \\
\hline Etimesgut & 10355 & 56,8 & 5541 & 30,4 & 2261 & 12,4 & 84 & 0,5 & 0 & 0,0 & 18241 \\
\hline Gölbaş1 & 498 & 36,5 & 686 & 50,3 & 170 & 12,5 & 10 & 0,7 & 0 & 0,0 & 1364 \\
\hline Keçïren & 10964 & 46,6 & 6436 & 27,3 & 4723 & 20,1 & 1333 & 5,7 & 85 & 0,4 & 23541 \\
\hline Mamak & 5540 & 50,4 & 4316 & 39,3 & 751 & 6,8 & 284 & 2,6 & 92 & 0,8 & 10983 \\
\hline Sincan & 1109 & 30,3 & 1236 & 33,7 & 1286 & 35,1 & 25 & 0,7 & 10 & 0,3 & 3666 \\
\hline Yenimahalle & 7152 & 49,6 & 4069 & 28,2 & 2323 & 16,1 & 780 & 5,4 & 107 & 0,7 & 14431 \\
\hline Toplam & 42215 & 41,1 & 32450 & 31,6 & 20093 & 19,6 & 6028 & 5,9 & 1920 & 1,9 & 102706 \\
\hline
\end{tabular}

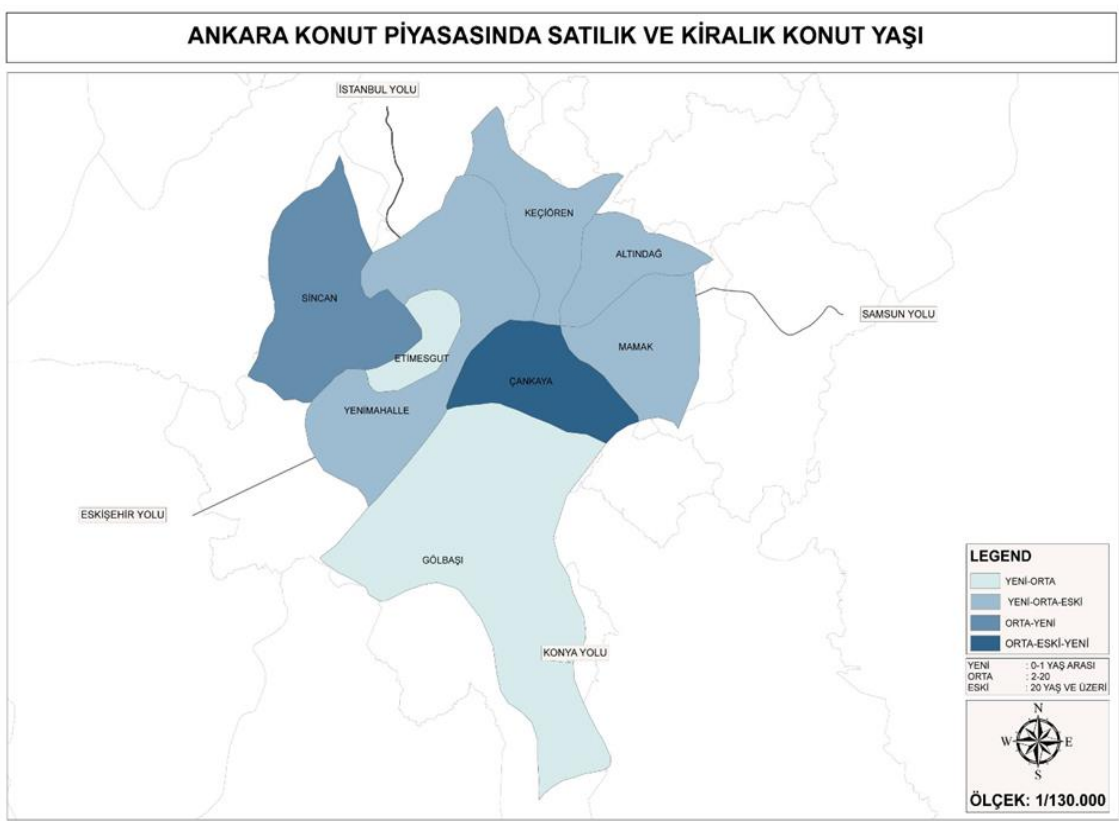

Konut Yaş *Yeni-0-1 yıl *Orta-2-20 yıl *Eski-20 üzeri yıl

Harita 4. Ankara konut piyasasında satılık ve kiralık konut yaşı

\section{Ankara Metropoliten Kenti Farklı Alt Konut Piyasalarındaki Ha- nehalkı Özellikleri İle Konut Kullanım Özellikleri İlişkisinin De- ğerlendirilmesi}

Çalışmanın evreni Ankara'da, 2011 yılında konutta ikamet eden hanehalkı sayısı 1.434.000'dir. Ankara metropoliten kentindeki 8 merkez ilçe içinde hanehalkı çeşitliliğini yansıtması çerçevesinde, ilçelerin sosyo- 
ekonomik yapıları, konut sunum biçimleri, türleri (toplu konut, apartman, kooperatif, müstakil vb.) ve konut kullanım biçimi (ilçelerin ev sahibi ve kiracı oranları) gibi faktörler göz önünde bulundurularak belirlenen ve 10-26 Şubat 2013 tarihlerinde gerçekleşen \%o3,6 örneklem oranı ile 534 adet hanehalkı anketinden (Tablo 7) elde edilen veriler hanehalkı özellikleri ve konut kullanım özellikleri ilişkisi, sosyo-demografik, sosyoekonomik ve alt piyasa özellikleri bağlamında ele alınmaktadır.

Tablo 7. Hanehalkı anketlerinin konut kullanım biçimine ve ilçelere göre dağılımı

\begin{tabular}{l|c|c|c|c}
\hline İlçeler & $\begin{array}{c}\text { Mülk Sahibi Anketi } \\
\text { sayısı }\end{array}$ & $\begin{array}{c}\text { Kiracı Anketi } \\
\text { sayısı }\end{array}$ & $\begin{array}{c}\text { Toplam anket } \\
\text { sayısı }\end{array}$ & $\mathbf{\%}$ \\
\hline Altındă̆ & 30 & 20 & 50 & 9.40 \\
\hline Çankaya & 64 & 36 & 100 & 18.70 \\
\hline Etimesgut & 40 & 28 & 68 & 12.70 \\
\hline Gölbaşı & 23 & 8 & 31 & 5.80 \\
\hline Keçiören & 73 & 35 & 108 & 20.20 \\
\hline Mamak & 42 & 20 & 62 & 11.6 \\
\hline Sincan & 35 & 12 & 47 & 8.80 \\
\hline Yenimahalle & 44 & 24 & 68 & 12.70 \\
\hline 8 İlçe Toplam & 351 & 183 & 534 & 100 \\
\hline
\end{tabular}

Bu bölümde Ankara metropoliten kentinde ilçe temelli alt konut piyasalarının arz (konut özellikleri) ve talep (hanehalkı) yönü arasındaki ilişkinin değerlendirilmesi amacı ile hanehalklarının sosyo-ekonomik özellikleri ve konut özelliklerine ilişkin çapraz tablolar oluşturulmuş ve ki-kare analizleri yapılmıştır. Ayrıca çapraz tablolar ile mekan/alt piyasa ile ilişkili olduğu saptanan değişkenlerin ki-kare analiz sonuçları da değerlendirilmiştir.

\section{Sosyal ve Demografik Özellikler}

Anket yapılan hanehalkı üyelerinin \%35,8'i kadın \%64,2'si ise erkek, $\% 62,0 ' 1$ hanehalkı reisi 38,0'1 ise hanehalkı reisi eşidir. Hanehalkı reislerinin \%21,7'sinin lise, \%6,2'sinin ön lisans ve \%28,3'ünün üniversite mezunu olduğu görülmektedir. Buna karşın hanehalkı reislerinin \%0,6'sı okuryazar olmayan, \%23,4'ü ilkokul ve \%12,4'ü ortaokul mezunudur. Hanehalkı reis eşlerinin \%24,5'inin lise, \%5,1'inin ön lisans ve \%17,0'ının üniversite mezunu olduğu görülmektedir. Buna karşın \%5,1 okuryazar olmayan, \%37,7 ilkokul ve \%9,7 oranında da ortaokul mezunu hanehalk- 
ları olduğu görülmektedir. Hanehalklarının \%33,2'si "1 çocuklu", \%37,2'si "2 çocuklu", \%10,3'ü "3 çocuklu", \%1,9'u "4 çocuklu" ve 0,4'ü "5 çocuklu" dur.

Hanehalklarının medeni durumu ile konutu paylaşım biçimi arasında anlamlı ilişki vardır (Tablo 8). Bekar hanehalklarının konutlarını yalnız ya da bir başkası ile paylaşımlı kullandıkları görülmektedir. Evli hanehalklarının ise büyük çoğunluğu çekirdek aile, küçük oranda da geniş aile olarak konutlarını kullanmaktadır. Boşanmış hanehalklarının ise konutlarını ya yalnız ya da çocukları ile paylaştıkları görülmektedir. Eşini kaybetmiş hanehalkları da konutlarını ya yalnız, ya ebeveynlerinin yanına dönerek geniş aile içinde ya da çocukları ile birlikte kullanmaktadır. Konutunu yalnız kullanan hanehalkları bekar, boşanmış, eşini kaybetmiş hanehalklarından oluşabilmektedir. Konutunu paylaşımlı kullanan hanehalkları genellikle bekar hanehalklarından oluşmaktadır. Konutunu çekirdek aile olarak kullanan hanehalklarının tümü evli hanehalklarıdır. Konutunu geniş aile olarak kullanan hanehalkları ise evli ve evine boşanma, eş kaybı vb. farklı nedenlerden geri dönmüş hanehalklarından oluşmaktadır.

Tablo 8. Hanehalklarının medeni duruma göre konutu paylaşma biçimi

\begin{tabular}{|c|c|c|c|c|c|c|c|c|c|c|c|c|}
\hline \multirow{3}{*}{$\begin{array}{l}\text { Medeni } \\
\text { Durum }\end{array}$} & \multicolumn{12}{|c|}{ Hanenin Paylaşım Biçimi } \\
\hline & \multicolumn{2}{|c|}{$\begin{array}{c}\text { Yalnız } \\
\text { oturuyor }\end{array}$} & \multicolumn{2}{|c|}{$\begin{array}{l}\text { Paylaşımlı } \\
\text { oturuyor }\end{array}$} & \multicolumn{2}{|c|}{$\begin{array}{c}\text { Çekirdek } \\
\text { Aile }\end{array}$} & \multicolumn{2}{|c|}{ Geniş aile } & \multicolumn{2}{|c|}{$\begin{array}{c}\text { Eşinden ayrı } \\
\text { çocukları ile } \\
\text { birlikte }\end{array}$} & \multicolumn{2}{|c|}{$\begin{array}{c}\text { Eşini kaybetmiş } \\
\text { çocukları ile } \\
\text { birlikte }\end{array}$} \\
\hline & Sayı & $\%$ & Sayı & $\%$ & Sayı & $\%$ & Sayı & $\%$ & Sayı & $\%$ & Sayı & $\%$ \\
\hline Bekar & 30 & 51,7 & 28 & 48,3 & 0 & 0,0 & 0 & 0,0 & 0 & 0,0 & 0 & 0,0 \\
\hline Evli & 0 & 0,0 & 0 & 0,0 & 427 & 94,7 & 24 & 5,3 & 0 & 0,0 & 0 & 0,0 \\
\hline Boşanmış & 4 & 40,0 & 0 & 0,0 & 0 & 0,0 & 0 & 0,0 & 6 & 60,0 & 0 & 0,0 \\
\hline $\begin{array}{l}\text { Eşini } \\
\text { kaybetmiş }\end{array}$ & 5 & 33,3 & 0 & 0,0 & 0 & 0,0 & 1 & 6,7 & 0 & 0,0 & 9 & 60,0 \\
\hline \multicolumn{13}{|c|}{$\mathrm{X} 2=1156,075 \mathrm{p}=0,000$} \\
\hline
\end{tabular}

\section{Sosyo-Ekonomik Özellikler}

Hanehalklarının aylık gelir dağılımına bakıldığında; hanehalklarının \%8,1'inin 1000 ve altı TL, \%33,9'unun 1001-2000 TL, \%20,0'ının 20013000, \%14,2'sinin 3001-4000, \%20,0'ının 4000 ve üzeri TL aylık gelire sahip oldukları görülmektedir. Hanehalklarının \%88,4'ünün düzenli bir geliri bulunurken, \%11,6'sının düzenli geliri bulunmamaktadır. Hanehalklarının aylık gelir durumu genel olarak incelendiğinde minimum 500 TL, maksimum 12000 TL'dir. Minimum aylık gelirin asgari ücretin 
altına düşebildiği görülmektedir. Hanehalklarının \%56,4'ünün özel aracı bulunurken, \%43,6'sinın özel aracı yoktur. Hanede \%56,6 oranla "1" ve \%24,0 oranla "2" çalışan olduğu görülmektedir.

Hanehalkı reislerinin çalışma durumuna bakıldığında \%72,5'inin çalıştığı, \%21,5'inin emekli, \%3,9'unun çalışmadığ1 görülmektedir. Bunu öğrenci ve işsiz hanehalkı reisi takip etmektedir. Hanehalkı reislerinin eşlerinin \%69,8'i çalışmıyor iken \%20,7'si çalışmaktadır. Çalışan hanehalkı reisleri ağırlıklı olarak \%81,1 oranla ücretli çalışandır. Bunu işveren, kendi hesabına çalışan, ücretsiz aile işçisi biçiminde çalışanlar takip etmektedir. Çalışan hanehalkı eşlerinin ise genel olarak ücretli çalışan olduğu görülmektedir. Bunu işveren, kendi hesabına çalışan, ücretsiz aile işçisi takip etmektedir.

Hanehalklarının gelirleri ile yaşadıkları konutların satış/kira değerleri ve konut sunum biçimleri arasında anlamlı ilişkiler görülmektedir. Hanehalklarının yaşadıkları konut satış değeri ve konut kira değeri ile hanehalkının aylık toplam geliri arasında doğrusal bir ilişki olup, konutun satış ve kira değeri yükseldikçe hanehalkının da geliri artmaktadır (Tablo 9; Tablo 10).

Tablo 9. Hanehalklarının konut satış değerine göre aylık toplam geliri

\begin{tabular}{|c|c|c|c|c|c|c|c|c|c|c|}
\hline \multirow{3}{*}{ Konutun Satış Değeri } & \multicolumn{10}{|c|}{ Hanenizin aylık toplam geliri } \\
\hline & \multicolumn{2}{|c|}{1000 ve altı } & \multicolumn{2}{|c|}{$1001-2000$} & \multicolumn{2}{|c|}{$2001-3000$} & \multicolumn{2}{|c|}{$3001-4000$} & \multicolumn{2}{|c|}{4000 üzeri } \\
\hline & Sayı & $\%$ & Say1 & $\%$ & Say1 & $\%$ & Say1 & $\%$ & Sayı & $\%$ \\
\hline 100.000 TL ve altı & 14 & 17,3 & 43 & 53,1 & 14 & 17,3 & 4 & 4,9 & 6 & 7,4 \\
\hline $100.001-150.000 \mathrm{TL}$ & 10 & 7,9 & 55 & 43,7 & 30 & 23,8 & 14 & 11,1 & 17 & 13,5 \\
\hline $150.001-250.000 \mathrm{TL}$ & 2 & 2,5 & 21 & 26,3 & 15 & 18,8 & 23 & 28,8 & 19 & 23,8 \\
\hline $250.001-400.000 \mathrm{TL}$ & 0 & 0,0 & 0 & 0,0 & 3 & 10,3 & 8 & 27,6 & 18 & 62,1 \\
\hline 400.001 TL ve üstü & 3 & 21,4 & 3 & 21,4 & 1 & 7,1 & 1 & 7,1 & 6 & 42,9 \\
\hline $\mathrm{X} 2=99,829 \mathrm{p}=0,000$ & & & & & & & & & & \\
\hline
\end{tabular}

Tablo 10. Hanehalklarının konut kira değerine göre aylık toplam geliri

\begin{tabular}{|c|c|c|c|c|c|c|c|c|c|c|}
\hline \multirow{3}{*}{ Konutun Kira Değeri } & \multicolumn{10}{|c|}{ Hanenizin aylık toplam geliri } \\
\hline & \multicolumn{2}{|c|}{$\begin{array}{c}1000 \\
\text { ve altı TL }\end{array}$} & \multicolumn{2}{|c|}{$\begin{array}{c}1001-2000 \\
\text { TL }\end{array}$} & \multicolumn{2}{|c|}{$\begin{array}{c}2001-3000 \\
\text { TL }\end{array}$} & \multicolumn{2}{|c|}{$\begin{array}{c}3001-4000 \\
\text { TL }\end{array}$} & \multicolumn{2}{|c|}{$\begin{array}{c}4000 \mathrm{TL} \\
\text { üzeri }\end{array}$} \\
\hline & Sayı & $\%$ & Sayı & $\%$ & Sayı & $\%$ & Say1 & $\%$ & Sayı & $\%$ \\
\hline 500 TL ve alt1 & 5 & 8,5 & 32 & 54,2 & 12 & 20,3 & 5 & 8,5 & 5 & 8,5 \\
\hline $501-750 \mathrm{TL}$ & 6 & 8,7 & 17 & 24,6 & 21 & 30,4 & 10 & 14,5 & 15 & 21,7 \\
\hline $751-1000 \mathrm{TL}$ & 0 & 0,0 & 6 & 19,4 & 8 & 25,8 & 7 & 22,6 & 10 & 32,3 \\
\hline 1001 TL ve üstü & 3 & 15,8 & 0 & 0,0 & 3 & 15,8 & 2 & 10,5 & 11 & 57,9 \\
\hline $\mathrm{X} 2=44,350 \mathrm{p}=0,000$ & & & & & & & & & & \\
\hline
\end{tabular}


Hanehalklarının tercih ettikleri konut sunum biçimi ile gelirleri arasında da anlamlı ilişki vardır (Tablo 11). Hanehalkının geliri arttıkça büyük sermayeli site ve rezidans türü konutlarda yaşayan hanehalkı sayısının arttığ görülürken gelir düştükçe ise toplu konut ve dönüşüm sonrası konutların (TOKİ) tercih edildiğini görülmektedir.

Tablo 11. Hanehalklarının konut sunum biçimine göre gelirleri

\begin{tabular}{|c|c|c|c|c|c|c|c|c|c|c|}
\hline \multirow[t]{2}{*}{ Konut Sunum Biçimi } & \multicolumn{2}{|c|}{1000 ve altı } & \multicolumn{2}{|c|}{$1001-2000$} & \multicolumn{2}{|c|}{$2001-3000$} & \multicolumn{2}{|c|}{$3001-4000$} & \multicolumn{2}{|c|}{4000 üzeri } \\
\hline & say1 & $\%$ & say1 & $\%$ & say1 & $\%$ & Sayı & $\%$ & say1 & $\%$ \\
\hline Toplu konut (TOKİ) & 1 & 2,3 & 13 & 7,2 & 6 & 5,6 & 3 & 3,9 & 2 & 1,9 \\
\hline $\begin{array}{l}\text { Toplu konut (TOKİ- } \\
\text { dönüşüm) }\end{array}$ & 3 & 42,9 & 3 & $42,9 \%$ & 1 & 14,3 & 0 & 0,0 & 0 & 0,0 \\
\hline $\begin{array}{l}\text { Toplu konut (özel- } \\
\text { kooperatif) }\end{array}$ & 1 & 7,7 & 2 & 15,4 & 1 & 7,7 & 6 & 46,2 & 3 & 23,1 \\
\hline $\begin{array}{l}\text { Site (büyük sermayeli } \\
\text { özel şirket) }\end{array}$ & 3 & 6,3 & 9 & 18,8 & 12 & 25,0 & 8 & 16,7 & 16 & 33,3 \\
\hline $\begin{array}{l}\text { Rezidans (büyük } \\
\text { sermayeli özel şirket) }\end{array}$ & 4 & 80,0 & 0 & 0,0 & 0 & 0,0 & 0 & 0,0 & 1 & 20,0 \\
\hline Apartman(kooperatif) & 3 & 6,8 & 19 & 43,2 & 12 & 27,3 & 8 & 18,2 & 2 & 4,5 \\
\hline Apartman (yap-sat) & 17 & 7,3 & 85 & 36,5 & 50 & 21,0 & 33 & 14,2 & 48 & 20,6 \\
\hline Apartman (bireysel) & 11 & 8,5 & 50 & 38,5 & 24 & 18,5 & 13 & 10,0 & 32 & 24,6 \\
\hline Diğer & 0 & 0,0 & 0 & 0,0 & 0 & 0,0 & 5 & 55,6 & 3 & 33,3 \\
\hline
\end{tabular}

\section{Konut Kullanım Özellikleri ve Alt Piyasa İlişkisi}

Konut kullanım özelliklerinin alt piyasa ilişkisinin değerlendirilmesi amacıyla anket yapılan hanehalklarının konutlarının bulunduğu ilçe ile hanehalklarının sosyal yapısı, ekonomik yapısı ve konut özellikleri ilişkilerini değerlendirmek üzere çapraz tablolar oluşturulmuş ve ki-kare analizleri yapılmıştır.

\section{Hanehalklarının sosyal yapısı ve alt piyasa ilişkisi}

Sosyal yapıyı yansıtan hanede yaşayan kişi sayısı ile alt piyasalar arasında istatistiksel olarak anlamlı ilişki / fark bulunmaktadır $(\mathrm{p}<0,05)($ Tablo 12). Tek kişilik hanehalkı oranının en fazla olduğu ilçe Sincan (\%35), 2 kişilik hanehalkı oranının en fazla olduğu ilçe Keçiören (\%20,2)'dir. Çocuklu çekirdek ailelerin çoğunluğunu oluşturduğu 3 kişilik hanehalklarının en fazla olduğu ilçe Çankaya $(\% 29,4)$ ve 4 kişilik hanehalklarının en fazla olduğu ilçe ise Keçiören (\%23,3)'dir. Çok çocuklu ya da geniş ailelerin yer aldığ 5 ve üzeri kişilik hanehalkı oranı ise en fazla \%23,2 ile Keçiören İlçesindedir. 
Tablo 12. Konutun bulunduğu ilçeye göre hanede yaşayan kişi sayısı

\begin{tabular}{|c|c|c|c|c|c|c|c|}
\hline \multirow{2}{*}{\multicolumn{2}{|c|}{ İlçeler }} & \multicolumn{5}{|c|}{ Hanede Toplam Yaşayan Kişi Sayısı } & \multirow{3}{*}{$\begin{array}{l}\text { Toplam } \\
50\end{array}$} \\
\hline & & 1 & 2 & 3 & 4 & $5+$ & \\
\hline \multirow[t]{3}{*}{ Altındağ } & Sayı & 1 & 11 & 14 & 14 & 10 & \\
\hline & İlçe içindeki \% & 2,0 & 22,0 & 28,0 & 28,0 & 20,0 & 100,0 \\
\hline & $\begin{array}{l}\text { Hanede yaşayan kişi sayısı } \\
\text { içindeki \% }\end{array}$ & 2,5 & 10,1 & 9,2 & 9,3 & 12,2 & 9,4 \\
\hline \multirow[t]{3}{*}{ Çankaya } & Sayı & 4 & 19 & 45 & 25 & 7 & 100 \\
\hline & İlçe içindeki \% & 4,0 & 19,0 & 45,0 & 25,0 & 7,0 & 100,0 \\
\hline & $\begin{array}{l}\text { Hanede yaşayan kişi sayısı } \\
\text { içindeki \% }\end{array}$ & 10,0 & 17,4 & 29,4 & 16,7 & 8,5 & 18,7 \\
\hline \multirow[t]{3}{*}{ Etimesgut } & Sayı & 6 & 14 & 17 & 23 & 8 & 68 \\
\hline & İlçe içindeki \% & 8,8 & 20,6 & 25,0 & 33,8 & 11,8 & 100,0 \\
\hline & $\begin{array}{l}\text { Hanede yaşayan kişi sayısı } \\
\text { içindeki \% }\end{array}$ & 15,0 & 12,8 & 11,1 & 15,3 & 9,8 & 12,7 \\
\hline \multirow[t]{3}{*}{ Gölbaşı } & Sayı & 0 & 6 & 7 & 9 & 9 & 31 \\
\hline & İlçe içindeki \% & 0,0 & 19,4 & 22,6 & 29,0 & 29,0 & 100,0 \\
\hline & $\begin{array}{l}\text { Hanede yaşayan kişi sayısı } \\
\text { içindeki \% }\end{array}$ & 0,0 & 5,5 & 4,6 & 6,0 & 11,0 & 5,8 \\
\hline \multirow[t]{3}{*}{ Keçiören } & Sayı & 7 & 22 & 25 & 35 & 19 & 108 \\
\hline & İlçe içindeki \% & 6,5 & 20,4 & 23,1 & 32,4 & 17,6 & 100,0 \\
\hline & $\begin{array}{l}\text { Hanede yaşayan kişi sayısı } \\
\text { içindeki \% }\end{array}$ & 17,5 & 20,2 & 16,3 & 23,3 & 23,2 & 20,2 \\
\hline \multirow[t]{3}{*}{ Mamak } & Sayı & 0 & 14 & 23 & 14 & 11 & 62 \\
\hline & İlçe içindeki \% & 0,0 & 22,6 & 37,1 & 22,6 & 17,7 & 100,0 \\
\hline & $\begin{array}{l}\text { Hanede yaşayan kişi sayısı } \\
\text { içindeki \% }\end{array}$ & 0,0 & 12,8 & 15,0 & 9,3 & 13,4 & 11,6 \\
\hline \multirow{3}{*}{ Sincan } & Sayı & 14 & 9 & 8 & 8 & 8 & 47 \\
\hline & İlçe içindeki \% & 29,8 & 19,1 & 17,0 & 17,0 & 17,0 & 100,0 \\
\hline & $\begin{array}{l}\text { Hanede yaşayan kişi sayısı } \\
\text { içindeki \% }\end{array}$ & 35,0 & 8,3 & 5,2 & 5,3 & 9,8 & 8,8 \\
\hline \multirow[t]{3}{*}{ Yenimahalle } & Sayı & 8 & 14 & 14 & 22 & 10 & 68 \\
\hline & İlçe içindeki \% & 11,8 & 20,6 & 20,6 & 32,4 & 14,7 & 100,0 \\
\hline & $\begin{array}{l}\text { Hanede yaşayan kişi sayısı } \\
\text { içindeki \% }\end{array}$ & 20,0 & 12,8 & 9,2 & $14,7 \%$ & $12 \%$ & 12,7 \\
\hline \multirow[t]{3}{*}{ Toplam } & Sayı & 40 & 109 & 153 & 150 & 82 & 534 \\
\hline & İlçe içindeki \% & 7,5 & 20,4 & 28,7 & 28,1 & 15,4 & 100,0 \\
\hline & $\begin{array}{l}\text { Hanede yaşayan kişi sayısı } \\
\text { içindeki \% }\end{array}$ & 100,0 & 100,0 & 100,0 & 100,0 & 100,0 & 100,0 \\
\hline
\end{tabular}

Hanenin paylaşım biçimi konutların kullanım özellikleri çerçevesinde sosyal yapıyı yansıtan değişkenlerden birisidir. Yukarıda açılanan hanede yaşayan kişi sayısına paralel olarak hanenin paylaşım biçimi (yalnız, paylaşımlı, çekirdek aile, geniş aile, eşinden ayrı çocukları ile, eşini kaybetmiş çocukları ile) ile alt konut piyasası/ilçeler arasında istatistiksel olarak anlamlı ilişki / fark bulunmaktadır $(\mathrm{p}<0,05)$ (Tablo 13). Paylaşımlı hanehalkı oranı en fazla \%28,6 ile Çankaya'da, çekirdek aile hanehalkı 
oranı en fazla \%19,7 ile Çankaya ve Keçiören'de, geniş aile hanehalkı oranı en fazla \%32,0 ile Keçiören'de yer almaktadır.

Tablo 13. Konutun bulunduğu ilçeye göre haneyi paylaşma biçimi

\begin{tabular}{|c|c|c|c|c|c|c|c|c|}
\hline \multicolumn{2}{|l|}{ İlçeler } & \multicolumn{6}{|c|}{ Hanenin Paylaşım Biçimi } & \multirow{3}{*}{$\begin{array}{c}\text { Toplam } \\
\\
\\
\\
50\end{array}$} \\
\hline & & $\frac{N}{\text { స్ర }}$ & 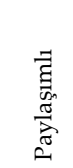 & 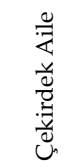 & 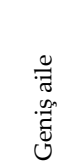 & $\begin{array}{c}\text { Eşinden } \\
\text { ayrı } \\
\text { çocukları } \\
\text { ile } \\
\text { birlikte }\end{array}$ & $\begin{array}{c}\text { Eşini } \\
\text { kaybetmiş } \\
\text { çocukları } \\
\text { ile birlikte }\end{array}$ & \\
\hline \multirow[t]{3}{*}{ Altındağ } & Sayı & 1 & 2 & 44 & 3 & 0 & 0 & \\
\hline & İlçe içi \% & 2,0 & 4,0 & 88,0 & 6,0 & 0,0 & 0,0 & 100,0 \\
\hline & $\begin{array}{l}\text { Hanenin paylaşım } \\
\text { biçimi içinde \% }\end{array}$ & 2,6 & 7,1 & 10,3 & 12,0 & 0,0 & 0,0 & 9,4 \\
\hline \multirow[t]{3}{*}{ Çankaya } & Sayı & 4 & 8 & 84 & 1 & 2 & 1 & 100 \\
\hline & İlçe içi \% & 4,0 & 8,0 & 84,0 & 1,0 & 2,0 & 1,0 & 100,0 \\
\hline & $\begin{array}{l}\text { Hanenin paylaşım } \\
\text { biçimi içinde \% }\end{array}$ & 10,3 & 28,6 & 19,7 & 4,0 & 33,3 & 11,1 & 18,7 \\
\hline \multirow[t]{3}{*}{ Etimesgut } & Sayı & 6 & 4 & 54 & 3 & 0 & 1 & 68 \\
\hline & İlçe içi \% & 8,8 & 5,9 & 79,4 & 4,4 & 0,0 & 1,5 & 100,0 \\
\hline & $\begin{array}{l}\text { Hanenin paylaşım } \\
\text { biçimi içinde \% }\end{array}$ & 15,4 & 14,3 & 12,6 & 12,0 & 0,0 & 11,1 & 12,7 \\
\hline \multirow[t]{3}{*}{ Gölbaşı } & Sayı & 0 & 0 & 30 & 1 & 0 & 0 & 31 \\
\hline & İlçe için \% & 0,0 & 0,0 & 96,8 & 3,2 & 0,0 & 0,0 & 100,0 \\
\hline & $\begin{array}{l}\text { Hanenin paylaşım } \\
\text { biçimi içinde \% }\end{array}$ & 0,0 & 0,0 & 7,0 & 4,0 & 0,0 & 0,0 & 5,8 \\
\hline \multirow[t]{3}{*}{ Keçiören } & Sayı & 7 & 4 & 84 & 8 & 1 & 4 & 108 \\
\hline & İlçe içi \% & 6,5 & 3,7 & 77,8 & 7,4 & 0,9 & 3,7 & 100,0 \\
\hline & $\begin{array}{l}\text { Hanenin paylaşım } \\
\text { biçimi içinde \% }\end{array}$ & 17,9 & 14,3 & 19,7 & 32,0 & 16,7 & 44,4 & 20,2 \\
\hline \multirow[t]{3}{*}{ Mamak } & Sayı & 0 & 2 & 57 & 2 & 0 & 1 & 62 \\
\hline & İlçe içi \% & 0,0 & 3,2 & 91,9 & 3,2 & 0,0 & 1,6 & 100,0 \\
\hline & $\begin{array}{l}\text { Hanenin paylaşım } \\
\text { biçimi içinde \% }\end{array}$ & 0,0 & 7,1 & 13,3 & 8,0 & 0,0 & 11,1 & 11,6 \\
\hline \multirow[t]{3}{*}{ Sincan } & Say1 & 13 & 5 & 26 & 2 & 1 & 0 & 47 \\
\hline & İ İlçe içi \% & 27,7 & 10,6 & 55,3 & 4,3 & 2,1 & 0,0 & 100,0 \\
\hline & $\begin{array}{l}\text { Hanenin paylaşım } \\
\text { biçimi içinde \% }\end{array}$ & 33,3 & 17,9 & 6,1 & $8,0 \%$ & 16,7 & 0,0 & 8,8 \\
\hline \multirow[t]{3}{*}{ Y.mahalle } & Say1 & 8 & 3 & 48 & 5 & 2 & 2 & 68 \\
\hline & İlçe içi \% & 11,8 & 4,4 & 70,6 & 7,4 & 2,9 & 2,9 & 100,0 \\
\hline & $\begin{array}{l}\text { Hanenin paylaşım } \\
\text { biçimi içinde \% }\end{array}$ & 20,5 & 10,7 & 11,2 & 20,0 & 33,3 & 22,2 & 12,7 \\
\hline \multirow[t]{3}{*}{ Toplam } & Sayı & 39 & 28 & 427 & 25 & 6 & 9 & 534 \\
\hline & İlçe içi \% & 7,3 & 5,2 & 80,0 & 4,7 & 1,1 & 1,7 & 100,0 \\
\hline & $\begin{array}{l}\text { Hanenin paylaşım } \\
\text { biçimi içinde \% }\end{array}$ & 100,0 & 100,0 & 100,0 & 100,0 & 100,0 & 100,0 & 100,0 \\
\hline
\end{tabular}


Ankara metropoliten kenti ilçelerinden Altındağ, Çankaya, Keçiören ve Etimesgut'ta \%80 civarında, Mamak ve Gölbaşı'nda \%90'nın üzerinde çekirdek aileler yer almaktadır.

\section{Hanehalklarının ekonomik yapısı alt piyasa ilişkisi}

Ankara metropoliten kentinde hanehalklarının ekonomik yapısının alt piyasa ile ilişkisinin belirlenmesi amacıyla yapılan ki-kare analizleri sonucu hanehalkı resinin çalışma durumu ile alt konut piyasası/ilçeler arasında istatistiksel olarak anlamlı ilişki / fark bulunmuştur $(p<0,05)$. Hanehalkı reisi çalışma durumu ile alt konut piyasası/ilçeler arasında da istatistiksel olarak anlamlı ilişki/fark bulunmaktadır $(\mathrm{p}<0,05)$. Hanehalkı reisi çalışmayan hanehalklarının \%23,8'i Gölbaşı'nda, \%19'u Mamak'ta, \%14,3'ü aynı oranla Keçiören, Yenimahalle ve Altındağ'da, \%9,5'i Etimesgut'ta, \%4,8'i Sincan'da yer almaktadır. Hanehalkı reisi çalışan hanehalklarının \%19,6'sı Çankaya'da, \%18,6'sı Keçiören'de, \%14,2'si Etimesgut'ta, \%12,7'si Yenimahalle'de, \%10,9'u Mamak'ta, \%10,3'ü Sincan'da, \%9,8'i Altındağ'da, \%3,9'u Gölbaşı'nda yer almaktadır.

Hanenin aylık toplam geliri ile alt piyasa/ilçeler arasında istatistiksel olarak anlamlı ilişki / fark bulunmuştur $(\mathrm{p}<0,05)$ (Tablo 14). Hanenin aylık toplam geliri 1000TL ve altında olan hanehalklarının \%18,6's1 aynı oranla Altındağ ve Mamak'ta, \%16,3'ü Keçiören'de, \%11,6'sı aynı oranla Etimesgut ve Sincan'da, \%9,3'ü aynı oranla Çankaya ve Yenimahalle'de, \%7,1'i Gölbaşı'nda bulunmaktadır. Hanenin aylık toplam geliri 4000 TL'nin üzerinde olan hanehalklarının \%36,4'ü Çankaya'da, \%17,8'i Keçiören'de, \%16,8'i Yenimahalle'de, \%12,1'i Etimesgut'ta, \%8,4'ü Gölbaşı'nda, \%5,6'sı Altındağ' da, \%1,9'u Mamak'ta ve \%0,9'u Sincan'da bulunmaktadır. Ankara metropoliten kenti ilçelerinde \%10'un üzerinde en düşük aylık gelire sahip hanehalkları Altındağ, Mamak ve Sincan'da yer almaktadır. Etimesgut'da ise düşük-orta gelirli hanehalkaları ağırlıklıdır, ancak diğer ilçelere göre en çeşitli gelirli hanehalklarına sahip ilçedir. Keçiören'de kısmen yüksek ve düşük-orta gelirli hanehalkları yer almaktadır. Yenimahalle ve Çankaya'da ağırlıklı olarak orta yüksek ve yüksek gelirli hanehalkları yer almaktadır. Gölbaşı ise düşük-orta ve yüksek gelirli hanehalklarını içermektedir. 
Tablo 14. Konutun bulunduğu ilçeye göre hanenin aylık toplam geliri

\begin{tabular}{|c|c|c|c|c|c|c|c|}
\hline & & \multicolumn{5}{|c|}{ Hanenin aylık toplam geliri } & \multirow[t]{2}{*}{ Toplam } \\
\hline & & $\begin{array}{l}1000 \text { ve } \\
\text { alt1 }\end{array}$ & $\begin{array}{l}1001- \\
2000\end{array}$ & $\begin{array}{l}2001- \\
3000\end{array}$ & $\begin{array}{l}3001- \\
4000\end{array}$ & $\begin{array}{l}4000 \\
\text { üzeri }\end{array}$ & \\
\hline \multirow[t]{3}{*}{ Altındağ } & Sayı & 8 & 26 & 6 & 3 & 6 & 49 \\
\hline & İlçe içindeki \% & 16,3 & 53,1 & 12,2 & 6,1 & 12,2 & 100,0 \\
\hline & Aylık toplam gelir içindeki \% & 18,6 & 14,4 & 5,6 & 3,9 & 5,6 & 9,5 \\
\hline \multirow[t]{3}{*}{ Çankaya } & Sayı & 4 & 13 & 12 & 28 & 39 & 96 \\
\hline & İlçe içindeki \% & 4,2 & 13,5 & 12,5 & 29,2 & 40,6 & 100,0 \\
\hline & Aylık toplam gelir içindeki \% & 9,3 & 7,2 & 11,2 & 36,8 & 36,4 & 18,7 \\
\hline \multirow[t]{3}{*}{ Etimesgut } & Sayı & 5 & 22 & 18 & 10 & 13 & 68 \\
\hline & İlçe içindeki \% & 7,4 & 32,4 & 26,5 & 14,7 & 19,1 & 100,0 \\
\hline & Aylık toplam gelir içindeki \% & 11,6 & 12,2 & 16,8 & 13,2 & 12,1 & 13,2 \\
\hline \multirow[t]{3}{*}{ Gölbaşı } & Sayı & 2 & 9 & 7 & 1 & 9 & 28 \\
\hline & İlçe içindeki \% & 7,1 & 32,1 & 25,0 & 3,6 & 32,1 & 100,0 \\
\hline & Aylık toplam gelir içindeki \% & 4,7 & 5,0 & 6,5 & 1,3 & 8,4 & 5,4 \\
\hline \multirow[t]{3}{*}{ Keçiören } & Say1 & 7 & 41 & 26 & 12 & 19 & 105 \\
\hline & İlçe içindeki \% & 6,7 & 39,0 & 24,8 & 11,4 & 18,1 & 100,0 \\
\hline & Aylık toplam gelir içindeki \% & 16,3 & 22,7 & 24,3 & 15,8 & 17,8 & 20,4 \\
\hline \multirow[t]{3}{*}{ Mamak } & Sayı & 8 & 31 & 15 & 6 & 2 & 62 \\
\hline & İlçe içindeki \% & 12,9 & 50,0 & 24,2 & 9,7 & 3,2 & 100,0 \\
\hline & Aylık toplam gelir içindeki \% & 18,6 & 17,1 & 14,0 & 7,9 & 1,9 & 12,1 \\
\hline \multirow[t]{3}{*}{ Sincan } & Sayı & 5 & 27 & 7 & 3 & 1 & 43 \\
\hline & İlçe içindeki \% & 11,6 & 62,8 & 16,3 & 7,0 & 2,3 & 100,0 \\
\hline & Aylık toplam gelir içindeki \% & 11,6 & 14,9 & 6,5 & 3,9 & 0,9 & 8,4 \\
\hline \multirow[t]{3}{*}{ Yenimahalle } & Sayı & 4 & 12 & 16 & 13 & 18 & 63 \\
\hline & İlçe içindeki \% & 6,3 & 19,0 & 25,4 & 20,6 & 28,6 & 100,0 \\
\hline & Aylık toplam gelir içindeki \% & 9,3 & 6,6 & 15,0 & 17,1 & 16,8 & 12,3 \\
\hline \multirow[t]{3}{*}{ Toplam } & Sayı & 43 & 181 & 107 & 76 & 107 & 514 \\
\hline & İlçe içindeki \% & 8,4 & 35,2 & 20,8 & 14,8 & 20,8 & 100,0 \\
\hline & Aylık toplam gelir içindeki \% & 100,0 & 100,0 & 100,0 & 100,0 & 100,0 & 100,0 \\
\hline
\end{tabular}

$\mathrm{X} 2=116,251 \mathrm{p}=0,000$

\section{Konut özellikleri ve alt piyasa ilişkisi}

Konut özelliklerinin mekana göre farklılık göstermesi de konut politikaları ve kent planlama ilişkisi çerçevesinde göz önünde bulundurulması gereken konulardan biridir. Ankara metropoliten kentinde konut özelliklerinin alt piyasa ile ilişkisinin belirlenmesi amacıyla yapılan ki-kare analizleri sonucu binanın yaşı, konutun satış değeri ve konutun kira değeri değişkenleri ile alt piyasa arasında anlamlı ilişki bulunmuştur.

Anket yapılan hanehalklarının oturduğu, yaşı 0-1 arasında olan yeni binaların \%21,4'ü aynı oranla Etimesgut, Keçiören ve Sincan'da, \%14,3'ü aynı oranla Çankaya ve Mamak'ta, \%7,1'i Gölbaşı'nda yer almaktadır. Yaşı 31'in üzerine de olan binaların \%37,5'i, Çankaya'da, \%35'i Mamak'ta, $\% 10^{\prime}$ u ayn oranla Altındağ ve Sincan'da, \%7,5'i Yenimahalle'de bulunmaktadır (Tablo 15). 
Tablo 15. Konutun bulunduğu ilçeye göre binanın yaş1

\begin{tabular}{|c|c|c|c|c|c|c|c|}
\hline & & \multicolumn{6}{|c|}{ Binanın yaşı } \\
\hline & & $0-1$ & $2-10$ & $11-20$ & $21-30$ & $31+$ & Toplam \\
\hline \multirow[t]{3}{*}{ Altındağ } & Sayı & 0 & 19 & 23 & 4 & 4 & 50 \\
\hline & İlçe içerisindeki \% & 0,0 & 38,0 & 46,0 & 8,0 & 8,0 & 100,0 \\
\hline & Binanın yaşı içerisindeki \% & 0,0 & 8,3 & 13,6 & 4,9 & 10,0 & 9,4 \\
\hline \multirow[t]{3}{*}{ Çankaya } & Sayı & 2 & 12 & 44 & 27 & 15 & 100 \\
\hline & İlçe içerisindeki \% & 2,0 & 12,0 & 44,0 & 27,0 & 15,0 & 100,0 \\
\hline & Binanın yaşı içerisindeki \% & 14,3 & 5,2 & 26,0 & 32,9 & 37,5 & 18,7 \\
\hline \multirow[t]{3}{*}{ Etimesgut } & Sayı & 3 & 48 & 17 & 0 & 0 & 68 \\
\hline & İlçe içerisindeki \% & 4,4 & 70,6 & 25,0 & 0,0 & 0,0 & 100,0 \\
\hline & Binanın yaşı içerisindeki \% & 21,4 & 21,0 & 10,1 & 0,0 & 0,0 & 12,7 \\
\hline \multirow[t]{3}{*}{ Gölbaşı } & Sayı & 1 & 22 & 6 & 2 & 0 & 31 \\
\hline & İlçe içerisindeki \% & 3,2 & 71,0 & 19,4 & 6,5 & 0,0 & 100,0 \\
\hline & Binanın yaşı içerisindeki \% & 7,1 & 9,6 & 3,6 & 2,4 & 0,0 & 5,8 \\
\hline \multirow[t]{3}{*}{ Keçiören } & Sayı & 3 & 54 & 22 & 15 & 14 & 108 \\
\hline & İlçe içerisindeki \% & 2,8 & 50,0 & 20,4 & 13,9 & 13,0 & 100,0 \\
\hline & Binanın yaşı içerisindeki \% & 21,4 & 23,6 & 13,0 & 18,3 & 35,0 & 20,2 \\
\hline \multirow[t]{3}{*}{ Mamak } & Sayı & 2 & 32 & 14 & 10 & 4 & 62 \\
\hline & İlçe içerisindeki \% & 3,2 & 51,6 & 22,6 & 16,1 & 6,5 & 100,0 \\
\hline & Binanın yaşı içerisindeki \% & 14,3 & 14,0 & 8,3 & 12,2 & 10,0 & 11,6 \\
\hline \multirow[t]{3}{*}{ Sincan } & Sayı & 3 & 14 & 22 & 8 & 0 & 47 \\
\hline & İlçe içerisindeki \% & 6,4 & 29,8 & 46,8 & 17,0 & 0,0 & 100,0 \\
\hline & Binanın yaşı içerisindeki \% & 21,4 & 6,1 & 13,0 & 9,8 & 0,0 & 8,8 \\
\hline \multirow[t]{3}{*}{ Yenimahalle } & Sayı & 0 & 28 & 21 & 16 & 3 & 68 \\
\hline & İlçe içerisindeki \% & 0,0 & 41,2 & 30,9 & 23,5 & 4,4 & 100,0 \\
\hline & Binanın yaşı içerisindeki \% & 0,0 & 12,2 & 12,4 & 19,5 & 7,5 & 12,7 \\
\hline \multirow[t]{3}{*}{ Toplam } & Say1 & 14 & 229 & 169 & 82 & 40 & 534 \\
\hline & İlçe içerisindeki \% & 2,6 & 42,9 & 31,6 & 15,4 & 7,5 & 100,0 \\
\hline & Binanın yaşı içerisindeki \% & 100,0 & 100,0 & 100,0 & 100,0 & 100,0 & 100,0 \\
\hline
\end{tabular}

Konut satış değerleri bulunduğu alt piyasaya göre farklılaşabilmektedir. Anket yapılan hanehalklarının oturduğu, satış değeri 100.000TL'den düşük konutların \%26,2'si Sincan'da, \%21,4'ü Keçiören'de, \%17,9'u Mamak'ta, \%14,3'ü Altındağ'da, \%11,9'u Etimesgut'ta, \%6'sı Gölbaşı'nda, $\% 2,4$ 'ü Yenimahalle' de yer almaktadır. Satış değeri 450.000TL'nin üzerinde olan konutların \%52,6'sı Yenimahalle'de, \%42,1'i Çankaya'da, \%5,3'ü Sincan'da yer almaktadır (Tablo 16). 
Tablo 16. Konutun bulunduğu ilçeye göre konutun yaklaşık satış değeri

\begin{tabular}{|c|c|c|c|c|c|c|c|}
\hline \multicolumn{2}{|l|}{ i̇lçeler } & \multicolumn{5}{|c|}{ Konutunuzun satış değeri (TL) } & \multirow{2}{*}{$\begin{array}{c}\text { Toplam } \\
\\
30 \\
\end{array}$} \\
\hline Altındağ & Sayı & $\begin{array}{c}100.000 \\
12 \\
\end{array}$ & $\begin{array}{c}100.001- \\
150.000 \\
15\end{array}$ & $\begin{array}{c}150.001- \\
250.000 \\
3\end{array}$ & $\begin{array}{c}250.001- \\
400.000 \\
0\end{array}$ & $\begin{array}{c}400.001 \\
+ \\
0\end{array}$ & \\
\hline & İlçe içerisindeki \% & 40,0 & 50,0 & 10,0 & 0,0 & 0,0 & 100,0 \\
\hline & $\begin{array}{l}\text { Konutun satış değeri } \\
\text { içerisindeki \% }\end{array}$ & 14,3 & 11,6 & 3,7 & 0,0 & 0,0 & 8,7 \\
\hline \multirow[t]{3}{*}{ Çankaya } & Sayı & 0 & 9 & 29 & 18 & 8 & 64 \\
\hline & İlçe içerisindeki \% & 0,0 & 14,1 & 45,3 & 28,1 & 12,5 & 100,0 \\
\hline & $\begin{array}{l}\text { Konutun satış değeri } \\
\text { içerisindeki \% }\end{array}$ & 0,0 & 7,0 & 35,8 & 58,1 & 42,1 & 18,6 \\
\hline \multirow[t]{3}{*}{ Etimesgut } & Sayı & 10 & 14 & 12 & 4 & 0 & 40 \\
\hline & İlçe içerisindeki \% & 25,0 & 35,0 & 30,0 & 10,0 & 0,0 & 100,0 \\
\hline & $\begin{array}{l}\text { Konutun satış değeri } \\
\text { içerisindeki \% }\end{array}$ & 11,9 & 10,9 & 14,8 & 12,9 & 0,0 & 11,6 \\
\hline \multirow[t]{3}{*}{ Gölbaşı } & Sayı & 5 & 11 & 4 & 1 & 0 & 21 \\
\hline & İlçe içerisindeki \% & 23,8 & 52,4 & 19,0 & 4,8 & 0,0 & 100,0 \\
\hline & $\begin{array}{l}\text { Konutun satış değeri } \\
\text { içerisindeki \% }\end{array}$ & 6,0 & 8,5 & 4,9 & 3,2 & 0,0 & 6,1 \\
\hline \multirow[t]{3}{*}{ Keçiören } & Sayı & 18 & 37 & 17 & 0 & 0 & 72 \\
\hline & İlçe içerisindeki \% & 25,0 & 51,4 & 23,6 & 0,0 & 0,0 & 100,0 \\
\hline & $\begin{array}{l}\text { Konutun satış değeri } \\
\text { içerisindeki \% }\end{array}$ & 21,4 & 28,7 & 21,0 & 0,0 & 0,0 & 20,9 \\
\hline \multirow[t]{3}{*}{ Mamak } & Sayı & 15 & 21 & 4 & 0 & 0 & 40 \\
\hline & İlçe içerisindeki \% & 37,5 & 52,5 & 10,0 & 0,0 & 0,0 & 100,0 \\
\hline & $\begin{array}{l}\text { Konutun satış değeri } \\
\text { içerisindeki \% }\end{array}$ & 17,9 & 16,3 & 4,9 & 0,0 & 0,0 & 11,6 \\
\hline \multirow[t]{3}{*}{ Sincan } & Sayı & 22 & 10 & 0 & 0 & 1 & 33 \\
\hline & İlçe içerisindeki \% & 66,7 & 30,3 & 0,0 & 0,0 & 3,0 & 100,0 \\
\hline & $\begin{array}{l}\text { Konutun satış değeri } \\
\text { içerisindeki \% }\end{array}$ & 26,2 & 7,8 & 0,0 & 0,0 & 5,3 & 9,6 \\
\hline \multirow[t]{3}{*}{ Y.mahalle } & Sayı & 2 & 12 & 12 & 8 & 10 & 44 \\
\hline & İlçe içerisindeki \% & 4,5 & 27,3 & 27,3 & 18,2 & 22,7 & 100,0 \\
\hline & $\begin{array}{l}\text { Konutun satış değeri } \\
\text { içerisindeki \% }\end{array}$ & 2,4 & 9,3 & 14,8 & 25,8 & 52,6 & 12,8 \\
\hline \multirow[t]{3}{*}{ Toplam } & Sayı & 84 & 129 & 81 & 31 & 19 & 344 \\
\hline & İlçe içerisindeki \% & 24,4 & 37,5 & 23,5 & 9,0 & 5,5 & 100,0 \\
\hline & $\begin{array}{l}\text { Konutun satış değeri } \\
\text { içerisindeki \% }\end{array}$ & 100,0 & 100,0 & 100,0 & 100,0 & 100,0 & 100,0 \\
\hline
\end{tabular}

$\mathrm{X} 2=186,727 \mathrm{p}=0,000$

Konut kira değerleri bulunduğu alt piyasaya göre farklılaşabilmektedir. Anket yapılan hanehalklarının oturduğu, kira değeri 500TL'den düşük konutların \%26,2'si Keçiören'de, \%19,7'si aynı oranla Altındağ, Mamak, Sincan'da, \%14,8'i Etimesgut'ta, yer almaktadır. Çankaya, Gölbaşı ve Yenimahalle'de kira değeri 500 TL'nin altında konut bulunmamaktadır. Kira değeri 1.000 TL'nin üzerinde olan konutların \%50'si Yenimahalle'de, \%35'i Çankaya'da, \%15'i Etimesgut'ta yer almaktadır (Tablo 17). 
Tablo 17. Konutun bulunduğu ilçeye göre konutun kira değeri

\begin{tabular}{|c|c|c|c|c|c|c|}
\hline \multicolumn{2}{|l|}{ İlçeler } & \multicolumn{5}{|c|}{ Konutunuzun kira değeri yaklaşık ne kadar? } \\
\hline & & \multirow{2}{*}{$\begin{array}{c}\begin{array}{c}500 \mathrm{TL} \\
\text { ve alt }\end{array} \\
12\end{array}$} & \multirow{2}{*}{$\begin{array}{c}501- \\
750 \mathrm{TL} \\
7\end{array}$} & \multirow{2}{*}{$\begin{array}{c}751- \\
1000 \mathrm{TL} \\
1\end{array}$} & \multirow{2}{*}{$\begin{array}{c}\begin{array}{c}1001 \mathrm{TL} \\
\text { ve üstü }\end{array} \\
0\end{array}$} & \multirow{2}{*}{$\begin{array}{c}\text { Toplam } \\
20\end{array}$} \\
\hline Altındağ & Sayı & & & & & \\
\hline & İlçe içerisindeki \% & 60,0 & 35,0 & 5,0 & 0,0 & 100,0 \\
\hline & Konutun kira değeri içerisindeki \% & 19,7 & 10,0 & 3,1 & 0,0 & 10,9 \\
\hline \multirow[t]{3}{*}{ Çankaya } & Sayı & 0 & 14 & 15 & 7 & 36 \\
\hline & İlçe içerisindeki \% & 0,0 & 38,9 & 41,7 & 19,4 & 100,0 \\
\hline & Konutun kira değeri içerisindeki \% & 0,0 & 20,0 & 46,9 & 35,0 & 19,7 \\
\hline \multirow[t]{3}{*}{ Etimesgut } & Sayı & 9 & 11 & 5 & 3 & 28 \\
\hline & İlçe içerisindeki \% & 32,1 & 39,3 & 17,9 & 10,7 & 100,0 \\
\hline & Konutun kira değeri içerisindeki \% & 14,8 & 15,7 & 15,6 & 15,0 & 15,3 \\
\hline \multirow[t]{3}{*}{ Gölbaşı } & Sayı & 0 & 8 & 0 & 0 & 8 \\
\hline & İlçe içerisindeki \% & 0,0 & 100,0 & 0,0 & 0,0 & 100,0 \\
\hline & Konutun kira değeri içerisindeki \% & 0,0 & 11,4 & 0,0 & 0,0 & 4,4 \\
\hline \multirow[t]{3}{*}{ Keçiören } & Sayı & 16 & 19 & 0 & 0 & 35 \\
\hline & İlçe içerisindeki \% & 45,7 & 54,3 & 0,0 & 0,0 & 100,0 \\
\hline & Konutun kira değeri içerisindeki \% & 26,2 & 27,1 & 0,0 & 0,0 & 19,1 \\
\hline \multirow[t]{3}{*}{ Mamak } & Sayı & 12 & 6 & 2 & 0 & 20 \\
\hline & İlçe içerisindeki \% & 60,0 & 30,0 & 10,0 & 0,0 & 100,0 \\
\hline & Konutun kira değeri içerisindeki \% & 19,7 & 8,6 & 6,3 & 0,0 & 10,9 \\
\hline \multirow[t]{3}{*}{ Sincan } & Sayı & 12 & 0 & 0 & 0 & 12 \\
\hline & İlçe içerisindeki \% & 100,0 & 0,0 & 0,0 & 0,0 & 100,0 \\
\hline & Konutun kira değeri içerisindeki \% & 19,7 & 0,0 & 0,0 & 0,0 & 6,6 \\
\hline \multirow[t]{3}{*}{ Yenimahalle } & Sayı & 0 & 5 & 9 & 10 & 24 \\
\hline & İlçe içerisindeki \% & 0,0 & 20,8 & 37,5 & 41,7 & 100,0 \\
\hline & Konutun kira değeri içerisindeki \% & 0,0 & 7,1 & 28,1 & 50,0 & 13,1 \\
\hline \multirow[t]{3}{*}{ Toplam } & Sayı & 61 & 70 & 32 & 20 & 183 \\
\hline & İlçe içerisindeki \% & 33,3 & 38,3 & 17,5 & 10,9 & 100,0 \\
\hline & Konutun kira değeri içerisindeki \% & 100,0 & 100,0 & 100,0 & 100,0 & 100,0 \\
\hline
\end{tabular}

\section{Tartışma ve Sonuç}

Ankara metropoliten kentinde ilçelerin farklı alt konut piyasalarını temsil ettiği kabulu ile, bu makalede; temel olarak alt konut piyasalarında- 
ki/ilçelerdeki hanehalkı ve konut özellikleri ve bunların birbirleri ile ilişkisi ele alınmaktadır. 16.12.2013-03.01.2014 tarihleri arasındaki emlak verisinden (126.017 konut ilani) elde edilen güncel konut piyasasında (piyasa sunumu) yer alan konut stokunun özellikleri ile 2013 yilı anket çalışmasına katılan farklı alt konut piyasalarındaki/ilçelerindeki hanehalklarının (534 hanehalkı) oturdukları konutların özellikleri (konut türü, konut değeri, konut büyüklüğü, konutun oda sayısı ve konutun yaşı) bir arada ele alındığında aşağıdaki değerlendirmeler yapılabilir.

Ankara metropoliten kentinin güncel konut piyasasındaki konut türleri ile ankete katılan hanehalklarının oturdukları konutların türleri paralel niteliktedir. Hem güncel konut piyasasında, hem ankete katılan hanehalklarının oturdukları konutların türü açısından bakıldığında, en yaygın konut türü apartman dairesidir. Kat Mülkiyeti Yasası'na paralel olarak hızla gelişen yap-sat üretim biçiminin bir yansıması olarak apartman türü konut, konut türleri içinde çok önemli bir paya sahiptir. Hem mevcut konut piyasasında hem ankete katılan hanehalklarının oturdukları konutların türü açısından bakıldığında, en yaygın ikinci konut türü ise villa / müstakil evdir. Villa / müstakil ev türü konutların konut türleri içinde göreli daha az bir paya sahip olması ise arazi politikalarına bağlı olarak bu konutların değerlerinin daha yüksek olması ve bu nedenle daha sinırlı bir grup (üst gelir grubu) tarafından tercih edilmesinin bir sonucudur. Hem mevcut konut piyasasında hem ankete katılan hanehalklarının oturdukları konutların türü açısından bakıldığında, en az rastlanan konut türü ise rezidanslardır. Ancak anketin gerçekleştirildiği dönemden bu yana rezidans türü konutların son dönemlerde giderek artan ve tercih edilen bir konut türü olduğu söylenebilir.

Ankara metropoliten kenti güncel konut piyasasındaki konutların satış ve kira değerleri ile ankete katılan hanehalklarının oturdukları konutların satış ve kira değerleri kısmen farklılık göstermektedir. Hem güncel konut piyasasındaki konutların hem de ankete katılan hanehalklarının oturdukları konutların yarıdan fazlası orta seviyede satış (100bin- 250bin TL) ve kira (500-1500 TL) değerine sahiptir. Ancak güncel konut piyasasındaki konutların satış ve kira değerlerinin daha yüksek olduğu görülmektedir. Ankete katılan hanehalklarının oturdukları konutlar, güncel konut piyasasındaki konutlara göre daha eskidir. Ankara metropoliten kentinde yapılan anket çalışmasına göre en düşük satış değerine sahip konut oranı Sincan, Altındağ ve Mamak'ta yer alırken, en yüksek satış değerine sahip konut oranı ise Yenimahalle ve Çankaya'da yer almakta- 
dır. En düşük kira değerine sahip konut oranı, satış değerinde olduğu gibi, Sincan, Altındağ ve Mamak'ta yer almaktadır. Yüksek kira değerine sahip konut oranı ise en yüksek Yenimahalle'dedir. Güncel konut piyasasında çok sayıda satılık ve kiralık yeni ve büyük konutun bulunması konut değerlerini arttırmaktadır. Satış ve kira değerlerinin belirlenmesinde, ilçelerin merkezi konumları, erişilebilirlikleri, altyapı olanakları, sosyo-ekonomik yapıları, kent içerisindeki prestij değerleri etkili olmaktadır. Bunların dışında, Ankara metropoliten kentinde yapılan anket çalışmasına göre hanehalkının geliri arttıkça büyük sermayeli site ve rezidans türü konutları tercih eden hanehalkı sayısının artması, hanehalkının geliri düştükçe ise toplu konut ve dönüşüm sonrası konutları (TOKI) tercih eden hanehalklarının artması, konut fiyatlarının daha düşük olduğu alt konut piyasalarında/ilçelerinde düşük gelirli hanehalkı sayısının artması gibi doğrusal ilişkiler; konut alt piyasalarının sunduğu konut sunum biçimleri/türleri ve fiyatlarının, hanehalklarının sosyoekonomik özelliklerinin bir yansıması olduğunu göstermektedir.

Ankara metropoliten kenti güncel konut piyasasındaki konut büyüklükleri ile ankete katılan hanehalklarının oturdukları konutların büyüklükleri kısmen farklılık göstermektedir. $150 \mathrm{~m}^{2}$ den büyük konutların güncel konut piyasasında daha fazla yer aldığı görülmektedir. İnşaat sektöründeki büyümeye ve hanehalklarının yaşam tarzlarında meydana gelen değişikliklere paralel olarak sunulan konut türleri de çeşitlenmekte ve bu durum güncel konut piyasasına yansımaktadır. Bu nedenle güncel konut piyasasında $150 \mathrm{~m}^{2}$ den büyük konutlar daha büyük oranda bulunmaktadır. Ayrıca satılık ve kiralık konutların gerek büyüklüklerine gerek oda sayılarına göre dağılımı ayrı değerlendirildiğinde; kiralık konutlar içinde küçük konutların, satılık konutlar içinde ise büyük konutların daha fazla olduğu görülmektedir. Ankara metropoliten kenti güncel konut piyasasındaki konutların oda sayısı ile ankete katılan hanehalklarının oturdukları konutların oda sayısı kısmen farklılık göstermektedir. Güncel konut piyasasında 1-2 odalı küçük konutların daha fazla yer aldığı görülmektedir. Mevcut konut piyasasında inşaat sektöründeki büyümeye ve hanehalklarının yaşam tarzlarında meydana gelen değişikliklere paralel olarak sunulan konut türleri de çeşitlenmektedir. Bu nedenle güncel konut piyasasında, çoğunlukla bekârların ve öğrencilerin tercih ettiği, 1-2 odalı (stüdyo tipi) konutlar daha büyük oranda bulunmaktadir. 
Anket yapılan konutların yaşları, Ankara metropoliten kenti güncel konut piyasasındaki konutların yaşlarından kısmen farklılık göstermektedir. Güncel konut piyasasında 0-1 yıllık konutların daha fazla yer aldığ1 görülmektedir. Türkiye'de inşaat sektörünün hızlı büyümesine paralel olarak, Ankara'da da çok fazla konut üretiminin olması yeni konutların piyasadaki payını arttıran en önemli unsurdur. Bu nedenle güncel konut piyasasında yeni / boş konutlar daha büyük oranda bulunmaktadır. Güncel konut piyasasında konut yaşları ilçeler çerçevesinde değerlendirildiğinde, Gölbaşı, Keçiören, Altındağ ve Etimesgut'ta ağırlıkla yeni konutların, Çankaya ve Sincan'da orta yaşlı konutların yer aldığı görülmektedir. Yenimahalle ve Mamak'taki konutların yarı yarıya yeni ve orta yaşlı konutlar olduğu dikkat çekmektedir. Konut piyasasında Etimesgut, Gölbaşı ve Sincan' da 20 yaşın üzerinde satılık ve kiralık konut bulunmadığı, 20 yaş üzeri konut oranının en fazla olduğu ilçenin ise Çankaya olduğu dikkat çekmektedir. Dönüşüm projeleri ile yoğun bir dönüşüm süreci yaşanan Altındağ ve Mamak gibi ilçeler ile TOKİ'nin Turkuaz, Yapracık gibi toplu konut projelerinin yer aldığı Etimesgut'ta mevcut emlak piyasasında yer alan konutların yarıdan fazlasının yaşı 0-1 arasındadır. Ankara'nın metropoliten ilçelerinde anket yapılan hanehalklarının oturduğu ve 2000lerden sonra yapılan yeni bina oranlarının en yüksek olduğu ilçeler ya da konut alt piyasaları Gölbaşı ve Etimesgut'dur. 1980lerin ortasından 2000lere kadar olan dönemlerde yapılan binaların oranlarının \%40lar civarında olduğu ilçeler Sincan, Altındağ ve Çankaya'dır. 1985 öncesi yapılan binaların oranı ise en yüksek Çankaya ve Mamak ilçelerinde yer almaktadır. Etimesgut'ta 21 yaş üzeri, Gölbaşı ve Keçiören'de ise 31 yaş üzerinde anket yapılan konut bulunmamaktadır. Bu bulgu aynı zamanda kentin tarihsel olarak geçmişten günümüze gelişim, büyüme, planlama ve kentleşme dinamikleri sürecinin de bir yansımasıdır. Kentin merkezi bölgelerinde eski konut stoku yer alırken, yenilenme süreci ile yeni binalar yer alırken, kentin göreceli olarak sonradan gelişen bölgelerinde yeni binaların daha fazla yer aldığı görülmektedir.

Ankara metropoliten kentinde farklı alt konut piyasalarındaki/ilçelerdeki hanehalkı ve konut özellikleri ve bunların birbirleri ile ilişkisini ele alan bu makalede güncel konut piyasasında (piyasa sunumu) yer alan konut stokunun özellikleri ile anket çalışmasına katılan farklı alt konut piyasalarındaki/ilçelerindeki hanehalklarının oturdukları konutların özellikleri (konut türü, konut değeri, konut büyüklüğü, konutun oda sayısı ve konutun yaşı) yukarıda kısaca tartışılmıştır. Bu bağlamda An- 
kara metropoliten kentinde yapılan anket çalışması ile hanehalklarının sosyal ve ekonomik yapısının mekâna-alt piyasalara (ilçelere) göre farkl1laştı̆̆ tespit edilmiştir.

Ankara metropoliten kentinde hanehalklarının ekonomik yapısının konut alt piyasaları ile ilişkisi değerlendirildiğinde Altındağ, Mamak ve Sincan'da düşük gelir gruplarının yer seçtiği görülürken Yenimahalle ve Çankaya'da ise çoğunlukla orta yüksek ve yüksek gelirli hanehalklarının yer aldığı görülmektedir. Etimesgut düşük-orta gelirli hanehalkları ağırlıklı olmak üzere diğer ilçelere göre en çeşitli gelirli hanehalklarına sahip ilçedir. Gölbaşı ise düşük-orta ve yüksek gelirli hanehalkalarının yer aldığı daha keskin ayrımlı bir yapıyı ortaya koymaktadır. Bu durum alt konut piyasalarını/ilçelerinin konut türleri (müstakil, site, rezidans gibi), kalitesi, ses yalıtımı, ısınma biçimi, güvenliği, büyüklüğü gibi konutun fiziki özellikleri; iş yerine yakınlığı, sağlık tesislerine yakınlığı, toplu taşım duraklarına, park, oyun, spor alanlarına yakınlığı, alışveriş olanaklarına yakınlığı konut fiyatlarında değişime neden konutun konumuna bağlı olarak değişen konut fiyatları ile kendi içinde de daha küçük alt piyasalara bölünmesi ile ilgilidir. Örneğin Gölbaşı İlçesi 1990lı yıllarla birlikte yoğunlaşan mevzi imar planlarıyla gelişme gösteren İncek Mahallesi'nin kentin orta üstü ve üst gelir grubuna hitap eden özellikle büyük konut projeleriyle kentin prestij bölgesi olarak gelişimini devam ettirdiği görülmektedir (Yenigül ve Gökler, 2017, s.68).

Kentin göreli olarak güneyini, güney batısını ve merkezini temsil eden Çankaya, Yenimahalle ve Gölbaşı (İncek mevki) ilçeleri ya da alt konut piyasaları göreli yeni konut alanları ile yeni yaşam tarzlarını pazarlayan daha yüksek satış ve kira değerleri ile üst gelir grubunu hedefleyen bir arza sahiptir. Çünkü konut talebinde sadece erişebilirlik, eğitim, sağlık, alışveriş vb. hizmetlere yakınlık gibi özellikler belirleyici olmamaktadır. Konutun "temalı bir projede yer alması", "yatırım değeri olması", "tasarımcısının ya da yüklenici firmasının marka değeri taşıması", "rezidans vb. farklı konut tipolojilerinin öne çıkarılması", çekici unsurlarla konut değiştirme arzusu yaratmak da talebi yönlendirmektedir (Uğurlar, 2016, s.590). Özellikle güney batı koridorunda yeni konut alanları ile yeni yaşam tarzları pazarlanmaktadır. Kentin göreli olarak daha üst gelir gruplarınca tercih ettiği kabul edilen alt konut piyasalarında kapalı site, rezidans türü konut alanları aracılığı ile hanehalklarına yeni yaşam tarzları sunulmakta; spor, havuz, alışveriş vb. sunulan hizmetler aracılığıyla tüketim ilişkileri ile şekillendirilmektedir. Gelir artıkça bu 
arza yönelik talepte artmaktadır. Bir bölgedeki konut fiyatları o bölgedeki konutları tercih eden ya da talep eden hanehalkı ya da tüketicilerin gelirlerinin yansımasıdır. Gökler'in (2017, s.304) ifade ettiği üzere Türkiye'de olduğu gibi Ankara'da da, arz-talep uyumsuzluğu kentin farklı ilçelerinde/semtlerinde farklı özellikler göstermesi, konut fiyatlarının mekânsal olarak farklılaşmasına ve hatta Ankara' da çok benzer özelliklere sahip konutların, farklı ilçe/semt/mahallelerde çok farklı fiyatlarda satışa sunulmasına neden olmaktadır. Konutun bulunduğu konum (ilçe, semt, mahalle vb.) konuta ekstra bir değer getirerek fiyatların farklı olmasına neden olabilmektedir (Gökler, 2017, Yayar ve Gül, 2014). Buradan hareketle literatürde Gribsy (1963), Rothenberg (1991) ve Davenport (2003)'un da ortaya koyduğu gibi, bu makalede de konut alt piyasalar1nın kendilerine özgü arz ve talebi olduğu sonucu ortaya konmaktadır. Ankara metropoliten kentinde her bir alt konut piyasası kendi içinde farklı konut satış-kira değerleri, "konutun kent içindeki göreli konumuna dayalı mekânsal özellikleri" (birincil), "konut çevresi ve konutun fiziki özellikleri ve sosyo-ekonomik, sosyo-demografik hanehalkı özellikleri ile (ikincil) ile alt piyasalara bölünebilmektedir. Bu nedenle farklı alt konut piyasalarının "arz ve talep" dinamiklerini dikkate alan aynı zamanda mekânsal planlamanın etkinliğini zayıflatmayan, mekânsal ve sınıfsal ayrışmaları derinleştirmeyen konut ve planlama politikalarının ve uygulamalarının geliştirilmesi önem taşımaktadır. 


\title{
Extended Abstract
}

\section{The Relationship Between Household and Housing Characteristics in the Context of Sub-Housing Markets: The Case of Ankara}

\author{
Aysu Uğurlar \\ Tanyel Özelçi Eceral \\ Aslı Gürel Üçer \\ Van Yüzüncü Yıl University \\ Gazi Üniversity \\ Gazi Üniversity
}

The housing market is a summation of sub-markets with specific supply, demand and spatial dynamics. In a sub-market, the demand for housing, whose value (price) is determined based on the characteristics of the house and its surroundings, is shaped according to the individual preferences of the households, which can change within the framework of their sociodemographic and socioeconomic characteristics. With the assumption that 8 central districts including Altındağ, Çankaya, Etimesgut, Gölbaşı, Keçiören, Mamak, Sincan and Yenimahalle represent the different housing submarkets in the metropolitan city of Ankara, the article deals with the household and residential properties in sub-housing markets/districts and their relationship with each other. The characteristics of the housing stock in the current housing market (market supply) obtained from the real estate data (126,017 housing ads) between 16.12.2013 and 03.01.2014 and the characteristics of the dwellings (housing type, housing value, size of housing, number of rooms in the dwelling and the age of the residence) in different housing sub-markets/districts of 534 households participated in the survey were handled together and evaluated briefly as follows. From this point, the types of housing in the current housing market of the metropolitan city of Ankara and the types of houses accommodated by the surveyed households are seen to be in line. It has been seen that the most common type of housing is apartment/flat both in the current housing market and in terms of the type of housings of the households surveyed. The second most common type of residence is villa/detached house, both in the current housing market and in terms of the type of housings of the households surveyed. Sales and rent values of the houses in the current housing market of the metropolitan city of Ankara and the sales and rent values of the dwellings of the households 
participating in the survey are partly different. More than half of the dwellings in both the current housing market and the households surveyed have medium level sales (100thousand - 250thousand Turkish Liras) and rent (TL 500-1500 TL) values. However, it has been seen that the sales and rent values of housing in the current housing market are found to be higher. The houses in which the households surveyed dwell were older than the houses in the current housing market. According to the survey conducted in the metropolitan city of Ankara, housings with the lowest sales value rate were located in Sincan, Altındağ and Mamak, while housings with the highest sales value rate were located in Yenimahalle and Çankaya. The dwellings with the lowest rent value rate were located in Sincan, Altındağ and Mamak as is the case for sales value. Housings with the highest rental rates were situated in Yenimahalle. The availability of large numbers of new and large dwellings for sale and rent in the current housing market increases housing values. According to the survey conducted in the metropolitan city of Ankara, linear relations such as the increase in the number of households that prefer large capital and luxurious residential type housing as household income increases along with the increase in the number of households that prefer mass-housing and post-transformation housing $\left(\mathrm{HDA}^{4}\right)$ as household income decreases, and the increase in the number of low-income households in housing sub-markets/districts where housing prices are lower showed that the housing supply types and prices offered by the housing sub-markets are a reflection of the socioeconomic characteristics of households. It was observed that low-income groups had chosen locations in Altındağ, Mamak and Sincan while middle-high and high-income households were mostly situated in Yenimahalle and Çankaya. Etimesgut was the district with the most various income households, mainly in low-middle income households group, compared to the other districts. Gölbaşı presented a more sharply differentiated structure with low-middle and highincome households. This was related to physical characteristics of housing, such as housing types (detached, residential compound, luxurious residence), quality, sound insulation, heating, security, and size in various subhousing markets/districts; changing housing prices depending on the location of housing such as proximity to the workplace, health facilities, public transport stops, vehicle parking, playgrounds, sports areas, shopping opportunities; and division into smaller sub-markets within itself. Çankaya,

\footnotetext{
${ }^{4}$ Housing Development Administration
} 
Yenimahalle and Gölbaşı (İncek locality) districts or sub-housing markets located in the south, south-west, and center of the city had a supply targeting higher income groups, with higher sales and rental values and that market new lifestyles with relatively new housing areas. In sub-housing markets considered to be preferred by the relatively higher income groups of the city, new life styles were offered to the households through residential compounds, luxurious residential type housing areas and sports, pool, shopping etc. facilities and services offered that were shaped by consumption relations. As income increases, the demand for this supply increases. Housing prices in a region is a reflection of the income of households or consumers who prefer or demand housing in that region. As put forward by Gribsy (1963), Rothenberg (1991) and Davenport (2003) in the related literature, in this article, too, it was revealed that housing sub-markets have their own specific supply and demand. In the metropolitan city of Ankara, each sub-housing market can be divided into sub-markets with different housing sales-rent values, spatial characteristics based on the relative position of the housing in the city (primary) and housing environment, physical characteristics of the residence, socioeconomic and socio-demographic household characteristics (secondary). Therefore, it is important to develop housing and planning policies and practices that take into account the supply and demand dynamics of different sub-housing markets, but also do not weaken the effectiveness of spatial planning and deepen spatial and class disagreements.

\section{Kaynakça/References}

Afşar, A., Yılmazel, Ö., Yılmazel, S. (2017). Konut fiyatlarını etkileyen faktörlerin hedonik model ile belirlenmesi: Eskişehir örneği. Selçuk Üniversitesi Sosyal Bilimler Enstitüsü Dergisi, 37, 195-205.

Ankara Kalkınma Ajansı. (2013). İstatistiklerle Ankara. Ankara: Ankara Kalkınma Ajansı Yayınları.

Alkan Gökler, L. (2017). Ankara'da konut fiyatları farklılaşmasının hedonik analiz yardımiyla incelenmesi, Megaron, 12(2), 304-315.

Balamir, M. (1996). Konut üreticileri, mülk konut, kiralık konut. Konut Araştırmaları Dizisi14, Ankara: Toplu Konut İdaresi. Başkanlığı

Bourassa, S. C., Cantoni, E. ve Hoesli, M. (2007). Spatial dependence, housing submarkets and housing prices. The Journal of Real Estate Finance and Economics, 35(2), 143-160.

Dalkılıç, B. ve Aşkın, M. (2018). Gayrimenkul ve konut sektörüne bakış. Emlak Konut: G. Y.O. 
Davenport, J. L. (2003). The effect of supply and demand factors on the affordability of rental housing. The Park Place Economist, 25 Ekim 2018 tarihinde http://digitalcommons.iwu.edu/parkplace/vol11/iss1/15/ adresinden erişildi.

Grigsby, W. G. (1963). Housing markets and public policy. University of Pennsylvania Press, Philadelphia.

Öney, E. (2002). Plansız yerleşmelerde 17 Ağustos 1999 Kocaeli depremi sonrası konut tercihlerinin analizi: Reşit Paşa örneği. Yayınlanmamış yüksek lisans tezi, İstanbul Teknik Üniversitesi, Fen Bilimleri Enstitüsü, İstanbul.

Öztürk, N. ve Fitöz, E. (2009). Türkiye'de konut piyasasının belirleyicileri: Ampirik bir uygulama. ZKÜ Sosyal Bilimler Dergisi, 5(10), 21-46.

Sarı, Ö. B. ve Khurami, E. A. (2018). Housing affordability trends and challenges in the Turkish case. Journal of Housing and the Built Environment, 1-20.

Strasheim, M., R. (1974). Housing market discrimination and black housing consumption. The Quarterly Journal of Economics, 88(1), 19-43.

Türel, A. 1996. Mülk konut, mülk konut, kiralık konut. Konut Araştırmaları Dizisi-14, Ankara: Toplu Konut İdaresi. Başkanlığı Başkanlığ1.

Türel, A. ve Koç, H. (2015). Housing production under less-regulated market conditions in Turkey. Journal of Housing and the Built Environment, 30(1), 53-68.

Türkiye İstatistik Kurumu (TÜİK), (2011). Nüfus ve konut araştırması. Ankara: Türkiye istatistik Kurumu Matbaası.

Türkiye İstatistik Kurumu (TÜIK), (2018). 15 Kasım 2018 tarihinde http://www.tuik.gov.tr/PreHaberBultenleri.do;jsessionid=32N3cTxKZSv9dH1FTR4G LqNf1TQ7FV3wqXyscLDgJj6ML8zczXL1!718202101?id=27823 adresinden erişildi.

Türkiye İstatistik Kurumu (TÜIK), (2013). 2002-2011 yılları yapı izin istatistikleri, 25.12.2013 tarihinde http://www.tuik.gov.tr/PreTablo.do?alt_id=1055 adresinden erişildi.

UAP, (2014). Ankara metropoliten alanı ve yakın çeoresi ulaşım ana planı hanehalkı araştırması sonuçları 2013. Ankara: Ulaşım Ana Planı Proje Ofisi Yayını.

Uğurlar, A. (2016). Housing as a mechanism for rent: housing market change and urban space production. Efe, R., Cürebal, İ., Nyussupova, G. ve Atasoy, E. (Editör), Recent Researches in Interdisciplinary Sciences içinde (ss. 588-602). St.Kliment Ohridski University Press, Sofia.

Uğurlar, A. ve Eceral, Ö.T. (2014). Ankara'da mevcut konut (mülk ve kiralık) piyasasına ilişkin bir değerlendirme. İdealkent, 12, 132-159.

Wu, C. Ve Sharma, R. (2012). Housing submarket classification: The role of spatial contiguity. Applied Geography, 32(2), 746-756.

Yayar, R. ve Gül, D. (2014). Mersin kent merkezinde konut piyasası fiyatlarının hedonik tahmini. Anadolu Üniversitesi Sosyal Bilimler Dergisi, 14(3), 87-100.

Yenigül, B., Gökler Alkan. L. (2017). Kentsel yayılma baskısı altında kalan yerleşimlerde sosyal sürdürülebilirlik: Ankara İncek Mahallesi örneği. Çağdaş Yerel Yönetimler, 26(1), .59-78.

Dr. Aysu Uğurlar, 1999 yllında Dokuz Eylül Üniversitesi Şehir ve Bölge Planlama Bölümü'nden lisans derecesini almıştır. Gazi Üniversitesi Şehir ve Bölge Planlama 
Bölümün'den 2006 yılında yüksek lisans ve 2013 yılında doktora derecesini derecesi almıştır. 2003 -2013 yılları arasında Gazi Üniversitesi Şehir ve Bölge Planlama Bölümün'de Araştırma Görevlisi olarak çalışmıştır. 2013'den itibaren Yüzüncü Yıl Üniversitesi Şehir ve Bölge Planlama Bölümün'de Yardımcı Doçent olarak çalışmaktadır. İlgi alanları konut politikaları, kentsel planlama, turizm, sürdürülebilirlik göstergeleri, yerel ekonomik kalkınmadır.

Dr. Aysu Uğurlar, graduated from Dokuz Eylul University, Faculty of Architecture, Department of City and Regional Planning in 1999. She received her M.R.P (2006) and her Ph.D (2013) degree from City and Regional Planning, Gazi University. She worked as Research Assistant City and Regional Planning, Gazi University, 2003-2013. Since 2013, She works as Assist. Prof. Dr. in the Department of City and Regional Planning at Yuzuncu Yil University. Her research interests are; housing policies, urban planning, tourism, sustainability indicators, local economic development.

E-mail: augurlar@gmail.com

Doç. Dr. Tanyel Özelçi Eceral, 1990 yılında Ortadoğu Teknik Üniversitesi Mimarlık Fakültesi Şehir ve Bölge Planlama Bölümü'nden mezun olmuştur. Aynı üniversitesnin Bölge Planlama programından yüksek lisans, Şehir ve Bölge Planlama Ana Bilim Dalı'ndan doktora derecesini almıştır. Kültür Bakanlığı ve GAP Bölge Kalkınma İdaresi'nde çalışmıştır. 2001 yılından bu yana Gazi Üniversitesi Mimarlık Fakültesi Şehir ve Bölge Planlama Bölümü'nde öğretim üyesi olarak çalışmaktadır. Bölgesel çalışmalar, kent ekonomisi ve kent planlama alanlarında çalışmaları bulunmaktadır.

Assoc. Prof. Dr. Tanyel Özelçi Eceral, received B.CP (1990) from City and Regional Planning Department, Faculty of Architecture, Middle East Technical University; M.RP (1993) from the Regional Planning Program and Ph.D. (2002) from the City and Regional Planning Program of Middle Esat Technical University. She had worked in Ministry of Culture and GAP Regional Development Administration. Recently works as Assoc. Prof. Dr. in the Department of City and Regional Planning, Faculty of Architecture at Gazi University. Research interests are regional studies, urban economics and urban planning.

E-mail: tozelci@gmail.com

Dr. Z. Aslı Gürel Üçer, Gazi Üniversitesi Şehir ve Bölge Planlama Bölümü'nü 1998 yılında bitirdi. 2002 yılında Orta Doğu Teknik Üniversitesi Kentsel Politika Planlaması ve Yerel Yönetimler Anabilim Dalı'ndan yüksek lisans ve 2009 yılında Gazi Üniversitesi Şehir ve Bölge Planlama Anabilim Dalı'ndan doktora derecesini aldı. Halen Gazi Üniversitesi Şehir ve Bölge Planlama Bölümünde öğretim görevlisidir. Kentsel politikalar, kent yönetimi, kentsel yaşam kalitesi ve kentsel hizmetler konularında çalışmaları bulunmaktadır.

Dr. Z. Aslı Gürel Üçer, graduated from the Department of City and Regional Planning at Gazi University in 1998. She received her M.S. degree from the Urban Policy Planning and Local Governments graduate program at METU in 2002 and her Ph.D. degree from the Department of City and Regional Planning at Gazi University in 2009. She is currently working as an instructor at Gazi University, Faculty of Architecture, Department of City and Regional Planning. Her main research interests are Urban policies, urban management, urban quality of life and urban services.

E-mail: asligurelucer@gmail.com

\section{Kaynakca Bilgisi / Citation Information}

Uğurlar, A., Özelçi Eceral, T. ve Gürel Üçer, A. (2018). Alt Konut Piyasaları Bağlamında Hanehalkı ve Konut Özelliklerinin İlişkisi: Ankara Örneği. IDEALKENT - Kent Araştırmaları Dergisi, 25, 800-833. 